\title{
Towards an understanding of the phases of goodwill accounting in four Western capitalist countries:
}

\section{From stakeholder model to shareholder model ${ }^{\text {th }}$}

\author{
Yuan Ding $^{\mathrm{a}}$, Jacques Richard ${ }^{\mathrm{b}}$ and Hervé Stolowy ${ }^{\mathrm{c}}$, \\ ${ }^{a}$ China-Europe International Business School (CEIBS), Shanghai, China \\ ${ }^{\mathrm{b}}$ University of Paris-Dauphine, France \\ ${ }^{\mathrm{c}} \mathrm{HEC}$ School of Management, Paris, France
}

Eighth draft - June 20, 2007

\footnotetext{
The authors would like to thank Salvador Carmona, David Cooper, Garry Carnegie, Guiseppe Galassi, Luca Zan and participants at the 3rd Workshop on Accounting and Regulation (Siena, Italy, 2004), the "Accounting, Auditing and Publication” Workshop (University of Paris Sorbonne, IAE, 2004) and the EAA Annual Congress (Göteborg, Sweden, 2005) for helpful comments. They also thank Hideki Fujii, Akihiro Noguchi, Chikako Ozu and Kenji Shiba for their valuable comments on Japanese regulations. The authors are particularly grateful to Anthony Hopwood (the Editor) and the two anonymous reviewers for their insightful suggestions. Responsibility for the ideas expressed, or for any errors, remains entirely with the authors. Hervé Stolowy acknowledges the financial support of the HEC Foundation (project F042) and the European Commission (project INTACCT). He is a member of the GREGHEC, CNRS Unit, UMR 2959. Jacques Richard is a member of the CEREG. Part of the research was conducted when the first author was affiliated to HEC School of Management, Paris. The authors thank Ann Gallon for her much appreciated editorial help.

*Corresponding author: Tel: +331396794 42.

E-mail address: stolowy@hec.fr.
} 


\section{Towards an understanding of the phases of goodwill accounting in four Western capitalist countries: From stakeholder model to shareholder model}

\section{Abstract}

The objective of this paper is to illustrate that the change in shareholders' attitude towards firms (from stakeholder model to shareholder model) influences the accounting treatments of goodwill. Our study is based on four countries (Great Britain, the United States, Germany, and France) and covers more than a century, starting in 1880. We explain that all these countries have gone through four identified phases of goodwill accounting, classified as (1) "static" (immediate or rapid expensing), (2) "weakened static” (write-off against equity), (3) “dynamic” (recognition with amortization over a long period) and (4) "actuarial” (recognition without amortization but with impairment if necessary). We contribute several new features to the existing literature on goodwill: our study (1) is international and comparative, (2) spans more than a century, (3) uses the stakeholder/shareholder models to explain the evolution in goodwill treatment in the four countries studied. More precisely, it relates a balance sheet theory, which distinguishes four phases in accounting treatment for goodwill, to the shift from a stakeholder model to a shareholder model, which leads to the preference for short-term rather than long-term profit, (4) contributes to the debate on whether accounting rules simply reflect or arguably help to produce the general trend towards the shareholder model, (5) demonstrates a "one-way" evolution of goodwill treatment in the four countries studied, towards the actuarial phase.

\section{Key words}

Goodwill - Accounting history - Social nature of accounting - Stakeholder/shareholder models - Corporate governance - France - Germany - Great Britain - United States 


\section{Introduction}

In positive accounting literature, the "stakeholder model" and "shareholder model" concepts have been emphasized (Ball, Kothari \& Robin, 2000, p. 243) to explain certain properties of accounting earnings (timeliness, conservatism). The stakeholder model (usually related to code-law countries) is a highly concentrated shareholding model where shareholders are mainly the founder families, the state, the bank or even trade unions and are actively involved in management of the company. The shareholder model (usually related to common-law countries) is not used as a legal term, but refers to a specific corporate governance model where ownership is dispersed and shareholders are separate from management. This literature offers us an interesting framework for analysing how the changes in actors’ forms of calculation impact accounting regulations (Robson, 1993).

Taking the accounting treatment for goodwill as an emblematic illustration, this article sets out to show that the direct associations between the stakeholder model and code-law countries, on the one hand, and between the shareholder model and common-law countries, on the other hand, are open to debate. Based on a social and historical study of four countries which have played a major role in the Western world economy during the $20^{\text {th }}$ century, Great Britain, the United States, Germany and France, we show that rather than corresponding to a clear dichotomy between common-law and code-law countries, these two models of corporate governance relate to a gradual shift: the stakeholder model was present in all four countries, and has evolved over time into the shareholder model. More precisely, we demonstrate that the four countries studied have a common starting point (stakeholder model), a time when shareholders were mainly insiders actively involved in management; and from that point, due to the capital markets' current importance, all of them have made their way to the common destination of professionalization of management and investors (shareholder model), but by different routes and at different paces. 
Leake (1914, p. 81) pointed out that the "word 'Goodwill' has been in commercial use for centuries” and cited a reference from the year 1571. Without looking so far back, our study still covers a period of more than a century, starting from the 1880s. Hughes (1982, p. 24) tells us that "accounting literature on goodwill appeared in ... periodicals or newspapers, such as The Accountant [which] started in 1874”.

Our paper concentrates on "acquired goodwill”: acquired either individually (goodwill purchased when buying assets other than by buying shares in a company [non-consolidation goodwill]) or in a business combination (goodwill purchased by a group when buying shares in a company [consolidation goodwill]) (Nobes \& Norton, 1996, p. 180). Internally-generated goodwill is not covered, as it involves specific issues in addition to those relating to acquired goodwill (see Jennings \& Thompson, 1996).

Many articles observe a wide diversity in both the regulations and treatments applied in practice to goodwill (Catlett \& Olson, 1968; Hughes, 1982; Arnold et al., 1994). In the United States, Walker (1938a) provides tables showing prevailing practices and the diversity in the treatment of goodwill in the balance sheet.

It is always difficult to divide prevailing accounting treatment into clearly dated phases. For this study, we decided to take a time of fundamental change as the start of a phase. That change generally concerns accounting regulations: newly-issued standards or exposure drafts that would later lead to the final standard constitute our primary sources. However, for the early stages (late $19^{\text {th }}$ century and early $20^{\text {th }}$ century) before formal accounting regulation of goodwill, our sources are court rulings and discussion papers written by leading scholars of the period ("doctrine”). We determine the phases on the basis of these elements.

In this article, we relate the stakeholder/shareholder models to a "balance sheet theory", developed by continental European scholars such as Schmalenbach (1908) with his concept of the "dynamic (versus static) balance sheet”. We extend these concepts to identify four phases in accounting treatment for goodwill. All the countries examined went through an initial 
phase that can be classified as "static": the idea was that the balance sheet should relate to the "end" of the firm, with items measured on the basis of liquidation value. This phase is marked by great reluctance to see goodwill as a true asset. In principle, this "unsightly, unwieldy and ‘un-valuable' asset”, to borrow Dicksee’s expression (1897, p. 47), was to be expensed immediately or at least rapidly. In the second phase, which we call "weakened static", goodwill was made to disappear within a short time of acquisition, but by means of a writeoff against equity. The third phase, called "dynamic", as it refers to the going concern (dynamic) assumption, saw widespread amortization of goodwill over a relatively long period. Finally, during the fourth, "actuarial” phase, goodwill came to be recognized as an asset, with no systematic reduction of value.

Both individual corporate accounts and consolidated accounts are considered. This study expands on previous literature on goodwill in five ways. First, it takes an international, comparative approach, focusing as it does on four countries. Second, it spans more than a century, starting in 1880. Third, it uses the stakeholder/shareholder models to explain the evolution in goodwill treatment in the four countries studied. More precisely, it relates a balance sheet theory, which distinguishes four phases in accounting treatment for goodwill, to the shift from a stakeholder model to a shareholder model. The result of this general trend is the preference for short-term rather than long-term profit. This idea is consistent with the works of economists (Lazonick \& O'Sullivan, 2000) who show that in the US, companies have gone from a "retain-and-reinvest" attitude (preferring immediate expenses to favour long-term profit) to a short-term profit orientation with distribution of dividends, explaining the move from a static phase to a dynamic and actuarial approach. Fourth, the article contributes to the debate about whether accounting rules simply reflect or arguably help to produce the general trend towards the shareholder model. Finally, we demonstrate a "oneway” evolution of goodwill treatment in the four countries studied, towards the actuarial phase. 
The remainder of this paper is organized as follows. The first section describes the existing literature on accounting regulation and the social nature of accounting which serves as the theoretical basis of our analysis. The second section is dedicated to the stakeholder/shareholder models and their relationship with the balance sheet theory referred to earlier. This conceptual framework is applied to the four phases of accounting treatment for goodwill. The third section examines these four historical phases of accounting for goodwill in four countries, and explains their successive development. This is followed by a discussion section and a final section concluding the article.

\section{Accounting regulation and the social nature of accounting}

\subsection{Theories explaining accounting regulation}

For decades, accounting regulation has been arousing interest among researchers. Booth and Cocks (1990, p. 511) examine accounting standard-setting and note that its study has been pursued from the perspective of five general research traditions: professional logic, neoclassical economics, cognitive psychology, the market for excuses and political lobbying. Lobbying has been extensively invoked in explaining standard-setting (Sutton, 1984; Tutticci, Dunstan \& Holmes, 1994; Weetman, Davie \& Collins, 1996; Van Lent, 1997; McLeay, Ordelheide \& Young, 2000; Zeff, 2002). The concept of “interest groups” has also been developed (Walker, 1987) and enriched (Robson, 1993). Conflicting agendas (Walker \& Robinson, 1994a) or inter-organizational conflict (Walker \& Robinson, 1994b) may also explain standard-setting. Booth and Cocks propose a power analysis (1990, p. 524).

Nobes (1992), setting out to explain the history of goodwill in the UK, proposes a cyclical model of standard-setting as a political process influenced by six parties: corporate managers, auditors, users, government, international opinion and upward force. Bryer (1995) develops another theory to explain standard SSAP 22 (ASC, 1984) on accounting for goodwill: he employs concepts from Marx’s political economy. 
Many authors have stressed the political aspects of standard-setting: Hope and Gray (1982) emphasize the role of power in the development of an R\&D standard; Laughlin and Puxty (1983) analyse the political process of standard-setting in the light of the problem of the conceptual framework and its viability; Power (1992) discusses brand accounting in the United Kingdom; Willmott et al. (1992) theorize the process of accounting regulation and the processes of social and political regulation generally, taking accounting for $R \& D$ in four advanced capitalist countries as an example; Fogarty, Hussein and Ketz (1994), in the US, develop an approach based on power, ideology and rhetoric; Klumpes (1994) analyzes the politics of rule development in the case of Australian pension fund accounting rule-making. Walker and Robinson (1993) review this literature. Harrison and McKinnon (1986) use change analysis to reveal the attributes and essential properties of regulation in a specific nation.

The political and economic consequences of accounting have also come under consideration (Solomons, 1978, p. 68; Zeff, 1978, p. 60; Solomons, 1983).

\subsection{Social nature of accounting}

It was several decades ago that accounting ceased to be considered as a pure technique and came to be seen as an instrument for social management and change (Hopwood, 1976, Preface; Burchell et al., 1980; Puxty, Willmott, Cooper \& Lowe, 1987), i.e. a "social rather than a purely technical phenomenon” (Burchell, Clubb \& Hopwood, 1985, p. 381). Hopwood (1976, p. 1), for example, says "the purposes, processes and techniques of accounting, its human, organizational and social roles, and the way in which the resulting information is used have never been static. (...) They have evolved, and continue to evolve, in relation to changes in the economic, social, technological and political environments of organizations”.

Harrison and McKinnon (1986, p. 233) point out that "since the early 1970s, policy formulation has been viewed as a social process; i.e. as the outcome of complex interactions 
among parties interested in or affected by accounting standards”. They refer to Watts and Zimmerman (1978), Holthausen \& Leftwich (1983) and Kelly (1983). In their work on value added in the United Kingdom, Burchell et al. (1985) review some existing theories of the social nature of accounting and conduct a social analysis. In the same vein, for Burchell et al. (1980), “accounting change increasingly emanates from the interplay between a series of institutions which claim a broader social significance”. Taking a different approach (based on Historical Materialism), Tinker et al. (1982) also argue that accounting is not neutral and that accountants "have been unduly influenced by one particular viewpoint on economic thought (utility based, marginalist economics) with the result that accounting serves to bolster particular interest groups in society” (p. 167).

As Burchell et al. say (1985, p. 381), “although the relationship between accounting and society has been posited frequently, it has been subjected to little systematic analysis”. We believe there is still some room for further contributions in this field. In this study, using goodwill as an example, we try to illustrate how the rise of the shareholder model has influenced accounting treatment.

This entire stream of literature emphasizes the influence of the social context on accounting. However, there could be a reverse effect: an influence exerted by accounting on the general economy and social trends. The work by Burchell et al. (1985, p. 381) already quoted above also demonstrates that "accounting, in turn, also has come to be more actively and explicitly recognised as an instrument for social management and change” (p. 381). One of their contributions is to highlight the intermingling of accounting and the social (p. 382). Tinker et al. (1982) also mention this interrelation, although more briefly, in stating that accountants bear a responsibility "for shaping subjective expectations which, in turn, affect decisions [our emphasis] about resource allocation, and the distribution of income between and within social classes” (p. 188). 
While Willmott et al. (1992)'s analysis concentrated on accounting, social and political regulations, taking accounting for $\mathrm{R} \& \mathrm{D}$ as an example, we will focus on accounting treatment and regulations on goodwill. We will also attempt to build on Burchell et al.'s work (1985) by showing the reverse influence of accounting on the social where goodwill is concerned.

\section{Conceptual framework of analysis: stakeholder/shareholder models, balance sheet theory and goodwill}

Our framework of analysis is based on the stakeholder/shareholder models, which are associated with the balance sheet theory as applied to the accounting treatment for goodwill.

\subsection{Stakeholder/shareholder models}

In this article, we enter the stakeholders vs. shareholders debate (see, e.g., Driver \& Thomson, 2002), taking the view that the evolution in regulations governing treatment of goodwill can be explained by the rise of the shareholder model and "constellations of material and ideological forces that are present within different nations” (Puxty, Willmott, Cooper \& Lowe, 1987).

The origin of this dichotomy theory can be traced back to the debate between Berle and Dodd on corporate accountability (Macintosh, 1999). During the 1930s, Berle and Dodd, two American law professors, publicly debated the question "to whom are corporations accountable?” (Berle, 1932; Dodd, 1932). Berle’s opinion was that the management of a corporation could only be held accountable to shareholders for their actions. Dodd believed that corporations were accountable to both their shareholders and the society in which they operated. Macintosh (1999) suggests that this debate "recognized in the absence of effective stockholder control, that full disclosure of information was the only effective means of ensuring that management would act in the interests of shareholders”. Furthermore, the views reiterated by Berle with Means, an economist, in The Modern Corporation and Private Property (Berle \& Means, 1932) are often considered as the beginnings of awareness of the 
corporate governance problem, since their book contains the first analysis of the issue in terms of separation of ownership and control (Baums, Buxbaum \& Hopt, 1994, Preface).

In a more recent phenomenon, researchers started to take an interest in the differences of ownership structure, and therefore corporate governance, between different countries (see, e.g., Roe, 1994 for a comparison between the USA, Germany and Japan).

These normative analyses on international differences in corporate ownership were then validated by empirical evidence from a study by La Porta, Lopez-de-Silanes and Shleifer (1999). Analysing the ownership structures of the 20 largest publicly traded firms in each of the 27 richest economies, they find that the United States combines relatively high ownership dispersion with good shareholder protection, a situation shared with other rich common-law countries, while in other countries, the firms studied are typically controlled by families or the State.

Based on this law and finance literature, the dichotomy between stakeholder and shareholder models is often viewed by positive accounting researchers as a clear-cut distinction between Anglo-American (common-law countries) and Continental European (code-law countries) business environments, and used to show the superiority of the American accounting model over those in other countries, and argue that capital-market driven full disclosure is the only worthwhile development model for accounting regulators in other countries (Ball, Kothari \& Robin, 2000; Hung, 2001; Hope, 2003).

Ball, Kothari and Robin (2000) were among the pioneers of this dichotomy between stakeholder and shareholder models in the empirical accounting literature. They refer to "the extent of political influence on accounting", and then go on to say (2000, p. 3): "In code-law countries, the comparatively strong political influence on accounting occurs at national and firm levels. Governments establish and enforce national accounting standards, typically with representation from major political groups such as labour unions, banks and business associations. At the firm level, politicization typically leads to a 'stakeholder' governance 
model, involving agents for major groups contracting with the firm. (...) Under the 'shareholder' governance model that is typical of common-law countries, shareholders alone elect members of the governing board, [and] payouts are less closely linked to current-period accounting income”.

We believe this theoretical framework offers a valuable basis for analyzing the change in shareholders' attitude toward firms. But we argue that at least two important dimensions are lacking in the extant debate. For one thing, there is no such clear-cut distinction in governance models between Anglo-American and Continental European business environments. Instead, in each country, we observe a shift, albeit at varying paces, from the stakeholder model to the shareholder model. This evolution is confirmed for Germany by Schilling (2001, p. 150) who mentions that "shareholders' interests play a much major role” and by Stoney and Winstanley (2001, p. 618) who observe that this country is "moving towards a more market-based (...) approach”. Our analysis should be seen as part of a debate which has generated mixed, not to say contradictory, results. While Letza, Sun and Kirkbride (2004, p. 252) advocate a paradigmatic shift from the shareholder model to the stakeholder model, Beaver (1999) questions the validity of the stakeholder model. In between, there is a developing body of literature bringing out the idea of a possible convergence between the two models to form a “hybrid” model (Jeffers, 2005; Ponssard, Plihon \& Zarlowski, 2005).

Even the literature referred to above (Ball, Kothari \& Robin, 2000; Ball, Robin \& Wu, 2003; Ball \& Shivakumar, 2005), which clearly separates the two models between commonlaw and code-law countries, includes some arguments supporting observation of a general move towards a shareholder model. In this stream of literature, the shareholder model is associated with a high level of conservatism proxied as a high sensitivity of earnings to any negative return on the firm's share price. In various countries, time-series empirical evidence proves that this sensitivity is on an upward trend. For example, Basu (1997) documents a steady increase over the thirty years between the 1960s and 1990s in the sensitivity of 
earnings to negative returns in the US. This evidence confirms that even in the US, the move towards a shareholder model has been a gradual process. In countries considered as stakeholder-dominated, empirical evidence also confirms an increase in this sensitivity. Ball et al. (2000) report that it increased significantly in France and Germany in the period 19901995. Giner \& Rees (2001) suggest that the phenomenon, known as asymmetric conservatism, continued to increase during the period 1996-98 in France, Germany and the UK. Basu (2001) uses the development of capital markets in Europe to explain this phenomenon. All this evidence indicates that the distinction between the stakeholder model and shareholder model is not so clear-cut after all, and the development of the shareholder model is closely tied up with the increasingly important role of the capital markets.

The other neglected aspect in our opinion, rather than seeking to validate or invalidate the superiority of the American accounting model (serving the interests of the shareholder model), is that the major difference between the stakeholder and shareholder models is the attitude towards long-term/short-term profit. As the extant literature shows, the stakeholder and shareholder models diverge on three major points: ownership structure, information asymmetry and the role of capital markets. The differences between the two governance models in all these three areas produce a preference for long-term profit in the stakeholder model but for short-term profit in the shareholder model, as we demonstrate below.

In practice, the stakeholder and shareholder models reflect two different types of relationship between shareholders and firms. In the former, ownership is often highly concentrated, with shareholders being mainly the founder families, the state, the bank or even trade unions, and actively involved in management of the company. There is less of an information asymmetry problem for these stakeholders: they can relatively reliably assess the company's future prospects. The shares of such a company are generally not very liquid and it is not easy to transfer ownership. The shareholders are therefore concerned with long-term financial viability and economic performance. Long-term contractual associations between 
the firm and stakeholders form one of the main proposals for stakeholding management (Letza, Sun \& Kirkbride, 2004, p. 243). In the shareholder model, ownership is dispersed and shareholders are separate from the firm's management team, with the result that owners of the company often have very weak or no involvement in corporate decision making. Besides, the sizeable physical and mental distance between the management team and shareholders considerably increases the level of information asymmetry. The capital market regulations (e.g. on anti-insider trading) limit their information access to publicly available information only. The shareholders have less visibility over the firm's future, and are thus more focused on its (short-term) financial performance. Furthermore, the shareholder model is closely associated with a highly developed (and therefore very liquid) capital market. In such a context, it is simple for shareholders to transfer their shareholding to somebody else, and this accentuates their short-term relationship with their invested companies. This situation is confirmed, a contrario, by certain authors who assert that the solution for improving corporate governance is "to provide an environment in which shareholders (particularly large and/or institutional shareholders) and managers are encouraged to share long-run performance horizons” (Letza, Sun \& Kirkbride, 2004, p. 245).

The long-term/short-term objectives divide is not new. The same authors remind their readers that the $19^{\text {th }}$ century debate on corporate governance involved two major theories: the "inherent property rights theory" (also called the "fiction theory"), which favoured profit maximization, and the "social entity theory" (also called the "organic theory") which put more emphasis on long-term growth (Letza, Sun \& Kirkbride, 2004, p. 248).

We observe that the role managers play has changed dramatically in the last hundred years. In the late $19^{\text {th }}$ and early $20^{\text {th }}$ centuries, most managers were the owners of their companies (stakeholder model). It was thus in their interest to preserve the company's long-term existence, and this was also in the interest of the creditors. But in most major companies 
nowadays, managers are employees like any others. With their stock option plans and other incentives, they act more like short-term investors (shareholder model).

We believe that the shift from the stakeholder model to the shareholder model is compatible with the "business systems" literature and the "comparative-business-systems approach" (Whitley, 1998, 1999a, 1999b). Business systems are conceived as distinctive patterns of economic organization that vary in their degree and mode of authoritative coordination of economic activities, and in the organization of, and interconnections between, owners, managers, experts, and other employees (Whitley, 1999b, p. 33). Nation states often develop distinctive business systems and Whitley discusses the importance of state boundaries (1999b, p. 44-45). However, while business systems are related to countries, they evolve over time, and Whitley (1999b, p. 182-208) provides evidence of changes in business systems in East Asian capitalist countries (Japan, South Korea, Taiwan). A few years later, Whitley (2005, p. 223) adds another idea: "the growing internationalization of investment and managerial coordination may weaken the national specificity of business systems”. All these arguments, based on the changes in dominant forms of economic organizations in market economies, can be transposed to the countries included in our scope. Although Whitley (2005, p. 223) limits his thought by referring to the "weakly institutionalized nature of the international business environment at the global level”, we will demonstrate in section 3 that as far as financial accounting is concerned, the international environment has had a major influence on accounting for goodwill. In conclusion, the concept of change in business systems reinforces the idea of evolution from one corporate governance model (the stakeholder model, in our study) to another (the shareholder model).

\subsection{Balance sheet theory and goodwill}

Continental European balance sheet theories first appeared in the $19^{\text {th }}$ century, in a context marked by a clash of interests between creditors and shareholders. From the introduction of 
the French commercial code (Code de commerce) in 1807, and publication of comments on the code (e.g., Delaporte, 1808, p. 122; Molinier, 1846, p. 194) until around 1870-1890, creditors and their defenders in France and Germany successfully imposed the "liquidation market value” as the basis for accounting legislation and court rulings (Richard, 2005a, 2005c). But towards 1870 in Germany, certain lawyers defending the interests of shareholders in large companies, particularly railway companies, led a revolt against the accounting concept of the Vermögensbilanz, or "liquidation balance sheet”. Based on the going concern concept, they proposed a new type of balance sheet, the Betriebsbilanz or "going concern balance sheet” considered more capable of generating regular dividend distribution, where fixed assets were stated at (amortized) cost (Richard, 2005a, 2005c). Von Strombeck (1878, p. 15), for example, argued that "the distribution of dividends should be based solely on going concern balance sheets, not liquidation balance sheets, so as to avoid fluctuations in value”.

A few years later, although he was also against liquidation balance sheets and in favour of the going concern principle, another German lawyer, Simon (1886, p. 161), published what amounts to a work of accounting theory with a new concept of the balance sheet, based on statement of fixed assets at their subjective value in use (Gebrauchswert) for a given businessman, rather than at cost as Von Strombeck recommended.

It can thus be considered that the three-faceted continental European balance sheet theories and the conflicting concepts of the balance sheet (liquidation value, cost "value" and value in use) emerged as early as 1886 (Richard, 2005b). This theoretical framework was then advanced in Germany by Schmalenbach (1919), who introduced a new vocabulary, classifying the at-cost balance sheet as "dynamic", as opposed to "static" liquidation value or value in use balance sheets.

This two-way classification and vocabulary are still in use in Germany, particularly in the work of Moxter (1984). In this paper, we use the representation by Richard (1996), who opts for a three-way classification: the word "static" is reserved for liquidation value balance 
sheets. Value in use balance sheets, which are very different from "static" liquidation balance sheets, are given a specific adjective, “actuarial”.

Continental European balance sheet theories were an important source of inspiration for Hatfield, the first great American accounting theorist, who was well-versed in German culture (Zeff, 2000; Richard, 2005b). Afterwards, with the coming of Paton's era (Paton \& Stevenson, 1922; Paton \& Littleton, 1940; Paton, 1962), “Anglo-Saxon” authors lost sight of these theories. But for the purpose of this article, they are particularly interesting, since due to their historical origins (the creditor-shareholder conflict) they provide a systematic link between the typology and conception of balance sheets and the evolution of the sociological and political context, and relate to the stakeholder/shareholder question that is the backdrop to this study.

Figure 1 summarises the different balance sheet concepts, highlighting the terminology used by the different authors.

Insert figure 1 about here

Schematically, the history of goodwill since the 1880s can be divided into four phases using a typology inspired by the continental European balance sheet theories discussed above (Richard, 2005b):

(1) The pure static phase (1) (Richard, 1996, p. 31, 33): The term static (from Latin "stare", to stop) is used to describe an accounting theory which assumes that the balance sheet, for the sake of creditor protection, shows liquidation values (the resale value in a liquidation process). It implies that goodwill is a fictitious asset, and applies immediate expensing or rapid amortization (over 5 years).

(2) The weakened static phase (2): this is an adjusted form of non-recognition of goodwill, applying a write-off against equity.

(3) The dynamic phase (3) (Richard, 1996, p. 51, 61-62). Here, the underlying assumption is no longer the liquidation of the company but the going concern (dynamic) approach, 
although goodwill is still assumed to have a finite life. This implies recognition of an asset, with application of amortization over a long period.

(4) The actuarial phase (4): this corresponds to the going concern assumption but without the idea that goodwill can “die”, leading to recognition of an asset, with impairment testing based on discounted (actuarial) cash flows ${ }^{1}$.

\subsection{Stakeholder/shareholder models applied to goodwill}

\subsubsection{Stakeholder model}

In a stakeholder model, shareholders are mainly blockholders such as families, state, banks or trade unions. Their presence is often a long-term commitment, and exits are relatively rare. In this situation, their main concern is protection and the durability of the corporate assets, in line with creditors of the firm. They are not therefore in favour of recording goodwill as an asset, preferring to have it eliminated as soon as possible (phase $\mathbf{0}$ of the balance sheet theory). Walker sums up their position very succinctly (1938a, p. 174).

The creditors, particularly banks, were sufficiently influential in the past to impose the write-off against equity solution (phase (2). The opinion of some actors in the early part of the $20^{\text {th }}$ century was expressed by McKinsey and Meech (1923, p. 538): "Bankers and businessmen generally prefer a balance sheet presenting only tangible assets to one loaded with goodwill and other intangible values ... in general, accumulated surplus should bear its share”. This opinion was echoed by Esquerré (1927, p. 41).

\subsubsection{Shareholder model}

The situation in the shareholder model is quite different. "Professional" shareholders or “rentier investors" (to use an expression of Hannah, 1983, p. 57), unlike family-owner

\footnotetext{
${ }^{1}$ We associate discounted cash flows with the term "actuarial” in the same way as Bogle (1889, p. 693) and Guthrie (1883, p. 6).
} 
shareholders, are generally short-term oriented and expect immediate, maximum profits. Many accounting historians have shown how, very often, creditors and family-owners share an interest in conservative accounting (see notably Edwards, 1989; Lemarchand, 1993, p. 529-581). The difference between the interests of professional shareholders and other stakeholders goes a long way back, as exemplified by Best’s (1885) remark: "shareholders are very apt to take one point of view and creditors and the outside public another”. In theory, the disappearance of the old conservative attitude towards goodwill should be associated with a rise in the influence of professional shareholders.

Total separation between ownership and management tends to work in favour of a nonamortization approach (phase $\mathbf{4}$ ), after the amortization approach (phase $\mathbf{3}$ ), which could be seen as a compromise. More prosaically, it could be said that shareholders will not stand for immediate or rapid charging of goodwill against income. At the end of the $19^{\text {th }}$ century, a good many authors, including supporters of immediate expensing/amortization, were already aware that shareholders could find themselves deprived of dividends due to drastic amortization of goodwill (see Matheson, 1884; More, 1891, p. 287; Guthrie, 1898, p. 429; Leake, 1914, p. 88).

Much more recently, the FASB itself (2001b, p. 3) acknowledged that "analysts and other users of financial statements, as well as company managements, noted that intangible assets are an increasingly important economic resource for many entities (...) and that financial statement users also indicated that they did not regard goodwill amortization expense as being useful information in analysing investments”. It went on (2001b, p. 5) to reiterate the importance of "financial statement users", saying they "will be better able to understand the investments made in those [goodwill and intangible] assets and the subsequent performance of those investments” (our emphasis). The accent is explicitly on performance measurement, and "ability to assess future profitability and cash flows" (FASB, 2001b, p. 5). 
The influence of the financial markets is visible in the same FASB Statement (2001b, p. 5), which concludes that "amortization of goodwill was not consistent with the concept of representational faithfulness, as discussed in FASB Concepts Statement No. 2” (FASB, 1980). It may sound surprising that it took more than 20 years to realize this inconsistency, but the FASB does explicitly link the reform to "the increase in merger and acquisition activity that brought greater attention to the fact that two transactions that are economically similar may be accounted for by different methods that produce dramatically different financial statement results” [the pooling-of-interests method and purchase method] (FASB, 2001b, Appendix 1, p. 5).

In our opinion, the capital markets' influence, and therefore the importance of the shareholder model, is also reflected in the notion of international pressure, or the desire for international comparability which is sometimes mentioned (Bryer, 1995, p. 305). The growing role of the capital markets is also due to the ever-increasing significance of goodwill in corporate accounts (Higson, 1998).

Figure 2 below summarizes the results of our analysis on the relationship between the shift from a stakeholder model to a shareholder model and accounting regulations for goodwill.

Insert figure 2 about here

Figure 2 shows that the shift from the stakeholder model to a shareholder model (from long-term to short-term profit orientation) is progressive, and corresponds to the four phases of the balance sheet theory described above which, in turn, can be related to goodwill treatment.

\section{The four historical phases of accounting for goodwill}

The move from the stakeholder model to the shareholder model resulted in changes in the regulations affecting goodwill treatment over the period examined. However, the four countries studied went through the same phases but at different times. 
Figure 3 below summarizes the four phases in the evolution of accounting for goodwill in the four countries studied.

Insert figure 3 about here

We do not include the IASC/IASB as a separate entity in our detailed analysis as the influence of its standard-setting on other countries has only been seen recently, i.e. in the late nineties with the trend for reducing the number of options (Walton, Haller \& Raffournier, 2003, p. 13) ${ }^{2}$.

\subsection{Phase 1: The static phase (non-recognition phase)}

\subsubsection{Great Britain (1880 - 1897)}

As emphasized by Dicksee and Tillyard (1920, p. 70), right up until 1900 the law and court rulings played a practically non-existent role in the treatment of goodwill in Great Britain. It is thus important to find out what practices most British accountants recommended.

In this phase, running from 1880 to about 1900, the dominant doctrine considered that goodwill was not a true asset, and should be immediately, or at least rapidly, expensed. The best proof of the widespread refusal to consider goodwill as an asset is in the writings of Gundry, one of the few authors in favour of seeing it as a "valuable asset” (1902, p. 663). Gundry, quoting Dicksee (1897) complains of "the general denouncement and deprecation of the term as an asset” (1902, p. 663).

The argument that goodwill would have no value in a bankruptcy situation was taken up by lawyers, such as Roby (1892, p. 293) and some accountants, including Knox (in Guthrie,

\footnotetext{
${ }^{2}$ For the sake of completeness, we will simply observe that the international accounting standard "Accounting for business combinations" (IASC, 1983) was adopted for the first time in 1983. Under paragraphs 39-42, several options were possible: (1) recognition as an asset and amortization over the useful life; (2) immediate reduction of earnings or (3) write-off against equity. These solutions correspond to our first three phases (static, weakened static and dynamic). This standard was revised in 1993, and the first two options were removed: goodwill had to be amortized over its useful life. This useful life was not to exceed five years unless a longer period, not exceeding twenty years, could be justified (IASC, 1993, § 40, 42). Only IFRS 3 (IASB, 2004b), which is mentioned in the body of the article, had any real influence on three of our studied countries (i.e. Great Britain, France and Germany).
} 
1898, p. 430), Stacey (1888, p. 605) and the author of a leading article in Time in 1905 (quoted by Dicksee \& Tillyard, 1920, p. 99). It is thus hardly surprising that a large number of accountants were in favour of immediately or rapidly writing off goodwill against profits (Matheson, 1884; Bourne, 1888, p. 604; More, 1891, p. 286; Roby, 1892, p. 293; see also Knox in Guthrie, 1898, p. 430).

Our conclusion from all this information is that the immediate expensing or rapid amortization approach, against current profits, was the standard practice up until 1900-1905. Globally speaking, this prudent accounting approach comes as no surprise: it is in line with the social and economic context of the period (Parker, 1965, p. 160; Hoppit, 1987, p. 16) where the stakeholder model was clearly the norm for corporate governance.

In contrast to the German situation (see below), there was strong opposition in Great Britain to the dominant purely static doctrine, ranging over several distinct views. For simplicity's sake, we identify the two main views.

The first, more widely-held view concerned proponents of the dynamic approach (which corresponds to our phase (3) (see Guthrie, 1898, p. 429). The second, and at the time the only credible alternative to the purely static approach, rallied authors who (also) proposed that goodwill should disappear from the accounts immediately, but by charging to equity (phase 2). This was the position of writers such as Dicksee (1897), whose later influence was to be fundamental (see below).

\subsubsection{United States $(1880$ - 1897)}

Throughout this period, the US economy was also dominated by the stakeholder model. Goodwill was not therefore considered as a true asset and was theoretically to be deducted from revenues. There was no regulation during this phase, but British writings and practices were very influential (Hughes, 1982, p. 24), and the situation appears to have been the same as in Great Britain. Symptomatically, the authors of one study of changes in the treatment of 
goodwill took their opinions from Harris $\left(1884\right.$, p. 11) and assert that prior to the late $19^{\text {th }}$ century, "accountants appeared in substantial agreement that amounts expended for goodwill should not be carried very long in the balance sheet” (Catlett \& Olson, 1968, p. 38).

Knight (1908, p. 197) speaks of goodwill as an "uncertain value” and deems that "the best course is to dispose of such an account through a charge to depreciation”, with writing off “encouraged”.

\subsubsection{Germany $(1880-1985)$}

Germany $^{3}$ was the country with by far the longest initial phase: from 1880 to 1985 . Prior to 1931, no law made any reference to treatment of goodwill, leaving only doctrine and court rulings as our sources. The German lawmakers of the time, under the influence of Napoleonic lawyers, adopted a static view of accounting: no item could be recognized as an asset unless it would have an individual market value in the event the company ceased to exist, i.e. went bankrupt. As a result of this doctrine most intangibles, particularly goodwill, that were not separable from the company and had no individual market value, had to be expensed immediately. This was to be the dominant practice for a great many years.

The only major voices raised in favour of recognizing acquired goodwill came from early supporters of the dynamic doctrine such as Simon and Fischer (Greve, 1933, p. 22). Only a few authors dared to propose recognition of goodwill followed by amortization over more than five years (Take, 1939, p. 116). Among the main proponents of this approach were Schmalenbach (1949), Müller (1915), Schreier (1928), Stern (1907), and Schmidt (1927) (on these authors, see Greve, 1933, p. 32; Take, 1939, p. 111-112), all of whom were in favour of long-term, systematic amortization.

\footnotetext{
${ }^{3}$ Although the country "Germany" did not exist as such at the beginning of the period under study, the following discussions apply to Prussia and the other German states, because after the Nürnberg conference (1857), a commercial code common to all German states (“Allgemeines Deutsches Handelsgesetzbuch” - ADHGB) was established as early as 1861 (Oberbrinkmann, 1990, p. 33).
} 
The first German law concerning goodwill was an emergency law of July 19, 1931. It added a new article to the Commercial Code (article 261) allowing acquired goodwill to be recognized as such only on condition it was then amortized by "appropriate annual amortization charges”. According to Greve (1933, p. 35) and Take (1939, p. 116), this law simply gave formal expression to the dominant doctrine of the time.

The measures introduced in 1931 were included without amendment in the law (AktG) of 1937 (article 133, paragraph 5), and then almost without amendment in the law (AktG) of 1965 (article 153, paragraph 5). The only noteworthy difference is that in 1965, the law stipulated that the systematic amortization against goodwill entered as an asset must be at least one-fifth annually. This remained applicable until 1985.

This exceptionally long static phase in Germany is consistent with the country's strong stakeholder model. For example, Roe (1994, p. 1936) documented that "CEOs at many large German companies face a small group of institutional voting blocks that controls nearly half of the stock voted”.

\subsubsection{France: the static phase $(1880$ - 1917)}

Reflecting the decisive influence of family owners and creditors (stakeholder model), the first phase in France was dominated by the purely static approach in both doctrine and case law: goodwill was not considered a true asset and was to be expensed immediately, or at the very least amortized rapidly.

In the 1880s, authors such as Didier (1885) with his "strict" balance sheet, CourcelleSeneueil (1872) and Vavasseur (1868), who stressed the difficulty of realizing fixed assets (in Verley, 1906, p. 121), recommended that assets, including goodwill, should be carried at liquidation value. To this way of thinking, a "good" asset was one with totally amortized goodwill. 
In the 1900s, most authors such as Kopf (1904, p. 27), Verley (1906, p. 39), Didier (1885) and Amiaud (1920, p. 6) also insisted that acquired goodwill was not a real asset. While they accepted recognition of this "fictitious" asset, rapid amortization (generally total amortization within less than five years) or a similar solution was required.

The dynamic approach of long-term amortization was only supported by Magnin (1912), whose writings, inspired by the German dynamic school, were fiercely criticized by most other authors. The only other real resistance to the static view came from French followers of the famous German lawyer Simon, principally Duplessis (1903) and above all Charpentier (1906), who were in favour of goodwill remaining in the balance sheet at its acquisition value, unless a fall in its "useful" value could be proved. This is in effect a conservative version of the actuarial approach.

\subsection{Phase 2: the weakened static phase (excluding France)}

This phase is identifiable in all the countries except France. Unlike the other countries where accounting law is independent of tax law, from 1917 the situation in France was dominated by tax concerns, which prevented the kind of change seen elsewhere. While the tax rule in the other countries was similar to the French rule of recognition without amortization, its influence was not as great as in France. France will therefore be examined in a separate section (3.3 below). France was to return to a "normal" situation as domestic tax influence declined and international influence increased.

\subsubsection{Great Britain (1897 - 1990)}

During this phase, since their immediate negative impacts on income harm dividend distribution, the purely static approaches (immediate expensing or rapid amortization against the year's profits) increasingly fell from favour, while a weakened static approach involving charging goodwill to equity became more popular. The demise of the immediate expensing or rapid amortization practice is visible from the work of influential authors of the first half of 
the $20^{\text {th }}$ century: Dicksee (1897), Garke and Fells (1922) and Lancaster (1927) all reject the practice of quick "writing down” against income. The dominant solution was to make goodwill disappear by charging it to equity, a practice that combines the basic static approach - goodwill is not an asset - with the possibility of dividend distribution, based on current profit. The shareholder model was growing in importance.

The idea of charging goodwill to equity came from the leading author for the second half of the $19^{\text {th }}$ century, Dicksee (1897). This "king” of British accounting was caught between two conflicting views:

- influenced by the static doctrine of the time, he accepted that goodwill is an asset of "arbitrary" value (1897, p. 45) that can be considered equivalent in nature to “Establishment expenses” (1897, p. 46) and must be treated with "the greatest caution” (1897, p. 46). He arrived at the conclusion that this asset should be eliminated "with all due speed” (1897, p. 45-46);

- $\quad$ on the other hand, he also had shareholder's interests in mind, and believed that goodwill "should not be written off out of profits” (1897, p. 46) because that is equivalent to creating “a secret reserve” (1897, p. 47).

Failing to find an optimum solution, Dicksee (1897), in agreement with Tillyard (1920, p. 106), appears to have finally accepted that acquired goodwill should be charged to reserves, particularly if the goodwill was artificially inflated. As in the previous period, many authors such as Hamilton (1914, p. 218), Lancaster (1927, p. 146) and Garke and Fells (1922) were drawn to this view for practical reasons.

This weakened static solution remained the standard approach in the UK until the end of the 1980s. Apart from reference to the influence of the dominant doctrine, one important fact supports this statement: despite an attempt to change the situation (a discussion paper dated 1980 with a proposal for capitalization and systematic amortization), at no time were the British lawmakers in a position to impose a solution contrary to the dominant practice 
(Paterson, 2002b). Furthermore, SSAP 22 (ASC, 1984, revised in 1989) still allowed goodwill to be written off immediately against reserves while offering an alternative treatment consisting of capitalization and amortization against future profits over its "useful economic life”. The first treatment was adopted almost universally (Arnold et al., 1994; Peasnell, 1996).

In our opinion, the weakened static solution is effectively a "convenient" variant of the purely static approach. Its aim is not to make goodwill an asset, but to make it disappear "softly, softly". Our view appears to correspond to the position defended in Great Britain (Holgate, 1990, p. 11).

\subsubsection{US (1897 - 1970)}

As in Great Britain, the static approach still dominated in the United States during this period, the basic view being that goodwill was not a real asset and should be made to disappear as soon as possible. However, rather than being charged to expenses, goodwill was increasingly charged against equity, and so the weakened static approach began to predominate as it did in England. On the theoretical aspect, Dicksee's ideas were widely echoed in the United States, where many authors favoured the solution of an immediate writeoff against retained earnings or capital surplus (Kester, 1922, p. 419; Lincoln, 1923; Mac Kinsey \& Meech, 1923, p. 538).

This philosophy was also reflected in the first US regulations. In 1917, a memorandum entitled “Uniform Accounting” issued by the American Institute of Accountants (predecessor to the American Institute of Certified Public Accountants) was accepted by the Federal Trade Commission and Federal Reserve Board, for application by companies wishing to obtain a loan. It recommends that goodwill should be "shown as a deduction from net worth" (AIA, 1917). While this treatment was only compulsory for financial statements produced for the purposes of a loan, it still reveals the state of mind at the time. 
There was also an increasing trend towards recommending recording goodwill at cost, followed by systematic amortization over its useful life or the period referred to for discounting to present value (Gilman, 1916, p. 195; Hatfield, 1918, p. 117; Paton \& Stevenson, 1922, p. 531; Hatfield, 1927; Yang, 1927, p. 196; Paton \& Littleton, 1940, p. 92). Others were in favour of recognition at cost with no systematic amortization (Dickinson, 1917, pp. 79-80; Freeman, 1921, p. 263; Bliss, 1924, p. 350; Esquerré, 1927, p. 130).

A significant event of this period was the serious 1929 economic crisis in American industry, which had several consequences in terms of treatment of goodwill. Its main impact was to reinforce the positions of those who saw goodwill as an unstable, if not undesirable, item (Walker, 1938b, p. 259).

\subsubsection{Germany (1985-2000)}

The main difficulty in analysis of this period lies in the fact that Germany introduced all European accounting directives into its national regulations at the same time, and reformed regulations governing both individual and consolidated accounts, with different solutions for goodwill. This change also coincided with the development of the German capital market.

\section{a) Individual accounts}

The German law of 1985, which incorporated the fourth EU directive into German regulations, includes a paragraph 255 with three sections on the treatment of goodwill in individual financial statements: (1) section 1: goodwill may be capitalized if it has been acquired; (2) section 2: if goodwill is capitalized, it must be amortized each subsequent year by at least 25 per cent; (3) section 3: the amortization may, however, "also be distributed systematically over the years which are likely to benefit” (see Ballwieser, 1996).

A first look at this rather indecisive text can lead to the following conclusions: the law does not impose treatment of goodwill as an asset, and allows (as before) immediate expensing of the corresponding disbursements. It can be even asserted that the "expense solution" remains 
the normal solution (Küting, 1997, p. 49; Duhr, 2003), as section 2 requires on principle that if the goodwill is capitalized, rapid amortization must be applied over a period of less than 5 years. This basic solution is explained, according to the doctrine, by the traditional conservatism principle (Walz, 1999, margin note 82; Duhr, 2003, p. 973; Ellrott, 2003, margin note 245).

But section 3 sheds some doubt on the "soundness" of the basic solution: for the first time in the history of Germany, an official text allows treatment of goodwill according to the dynamic approach, with capitalization and amortization over its full period of use.

Unsurprisingly given this ambiguity, which some specialists considered totally illogical (Busse von Colbe \& Ordelheide, 1993, p. 234; Küting, 2000, p. 102), the German doctrine is hesitant as to the nature of goodwill in individual accounts. It seems that the majority of German authors (see namely Busse von Colbe, 1986, p. 87; Förschle \& Kropp, 1986, p. 155; Söffing, 1988, p. 599; Weber \& Zündorf, 1989, p. 334; Förschle, 1995, margin note 7; Küting, 1997, p. 461; Ludz, 1997, p. 70; Baetge, Kirsch \& Thiele, 2002, p. 262) consider that neither the text of the law, nor the nature of goodwill (which is neither individually resalable nor individually valuable, and represents anticipated benefits) can confer on goodwill the status of a true asset. For a good number of these authors, goodwill, if capitalized, is only a "balance sheet-help” ("Bilanzierungshilfe”, an item which can in exceptional cases be recorded in the balance sheet, although it is not an asset), i.e. (in our own interpretation) a fictitious asset to be got rid of as rapidly as possible.

It can be concluded at this stage that although, from a regulation standpoint, the dynamic solution was beginning to break through (an undeniably new development in the German context), the basic solution, as confirmed by the predominant doctrine, remained the classic static conception. But this view must be cross-checked against the practices allowed for consolidated accounts. 


\section{b) Consolidated accounts}

The treatment of goodwill in consolidated accounts is codified by article 309-1 of the German Commercial Code. This article displays two fundamental oddities in comparison with its counterpart for individual accounts.

The first, which necessarily derives from the European text, is that, as a matter of principle, goodwill must be (not may be) capitalized (article 309-1, § 1). The different wording initially appears to indicate a different treatment compared to individual accounts. But there is a second oddity: the fact that the German legislator has used the flexibility of article $30 \S 2$ of the seventh EC directive, which allows member states to authorize companies to write off goodwill against equity. Many German authors who recommend unifying the rules between corporate and consolidated accounts, notably Busse von Colbe and Ordelheide (1993, p. 233) and Küting (1997, p. 455), refer to Niehus (1986, p. 239) in underlining that this flexibility results from a request by Great Britain, and constitutes an "error”. Whether or not this is true, this “error” has been legalized by the German legislator, who was under no obligation to do so. Article 309-1 paragraph 3 allows German groups to write off goodwill against consolidated retained earnings (but unlike the seventh directive, without specifying that the write-off must be immediate). To complete the scene, the German legislator has integrated other solutions allowed for individual accounts into the regulations for consolidated accounts: rapid amortization over a maximum of 5 years (paragraph 1) and amortization over the useful life (paragraph 2).

In terms of actual practices, the studies described by Busse von Colbe and Ordelheide (1993, p. 234, note 31) and Küting (2000) show that there was a real craze among German groups for the weakened static solution.

All this evidence makes it reasonable to state that due to the decisive importance of consolidated accounts, the 1985-2000 period in Germany was mainly dominated by the weakened static solution. 


\subsection{Phase 2 in France: the fiscal approach (1917 - 1982)}

From 1917, the tax administration began to intervene on the French accounting scene. Its theory of how goodwill should be treated was to have great influence on commercial doctrine and regulations. This phenomenon was unique in the four countries studied and lasted more than sixty years, from 1917 to 1982.

\section{a) The new doctrine of the French tax administration for individual accounts}

To begin with, when the first major French law on income taxes (the law of July 31, 1917) was enacted, the tax view was not openly hostile to the static approach. Article 4 of the law simply stated that taxable profit was the amount after deduction of all expenses, including “amortization generally accepted in the practices of each type of industry”. But subsequently, no doubt for budgetary reasons (Prospert, 1934, p. 71), the tax administration, in an instruction of March 30, 1918, refused all systematic (and a fortiori rapid) amortization of goodwill (Brière, 1934, p. 181). Despite some changes between 1918 and 1928, the French tax administration's position remained almost constantly as follows practically from 1928 to the modern day: (1) goodwill is an asset (but start-up costs are not); (2) goodwill cannot be systematically amortized; (3) goodwill can be reduced in exceptional circumstances.

\section{b) The influence of the tax administration's position on French accounting regulations}

Its influence was considerable. As early as 1944, Dalsace (1944, p. 142) was complaining about people "giving in” to the tax administration's ideas and pointed out that "all financial or fiscal considerations should be independent of asset valuation and amortization”. A few years later, an essay was published entitled “the hijacking of accounting by taxation” (Rives, 1962).

As regards goodwill, this hijacking was obvious from 1947. From the first French General Accounting Plan (Plan comptable général) (CNC, 1947, p. 79-81) it is clear that tax (i.e. actuarial) concerns had got the better of static and dynamic approaches: there is no (systematic) amortization account for goodwill, merely a provision account (but no indication 
of how it should be used). The situation was unchanged ten years later when the 1957 General Accounting Plan was issued (Poujol, 1965, p. 96), and continued until 1982.

In order to guarantee tax income, the French taxation system acted exactly like a shortterm-oriented investor, obliging firms to maximize their current income to the detriment of future earnings. France's acceptance of the tax administration's position disallowing systematic amortization of goodwill should not be taken to mean that France was more "advanced" than other countries; on the contrary, it is the sign of a delay in its development towards stock market capitalism.

\section{c) The case of consolidated accounts}

The above remarks concerned individual accounts. In the case of consolidated accounts, the situation in France also displayed a peculiarity compared to the other countries. Up to 1985, no strict obligation to establish consolidated accounts applied to French groups. During the whole period 1917-1982 the only French regulation that groups wishing to establish consolidated accounts could refer to was a CNC (Conseil National de la Comptabilité National Accountancy Council) report published in 1968 (CNC, 1968) and revised in 1978, but with no legal enforceability, which proposed that goodwill (at that time called "Prime d'acquisition des titres de participation” - “Acquisition premium on long-term investments”) should be maintained without change in the consolidated balance sheet (with no systematic amortization), “unless special circumstances justify reducing its value by constitution of a provision for impairment” (CNC, 1978, § 4102a). This solution visibly remained in line with the tax and accounting doctrines prevailing at that time for individual accounts, but as it had no legal value, groups were not obliged to follow this framework.

Some studies, however, seem to show that even in this period, a few French groups were beginning to follow the lead of the most "modern" American rules. For instance, Péchiney amortized its goodwill over 10 years in 1969 and 40 years in 1973 (Bensadon, 2002, p. 58). It 
was thus a time of conflict between what French regulations allowed and what French groups wanted.

\subsection{Phase 3: the dynamic phase}

\subsubsection{United States: the dynamic position comes out on top $(1970$ - 2001)}

In the period 1940-1970, three main phenomena were visible on the American scene: the doctrine and practice of writing off goodwill was in decline, the dynamic doctrine and practice began to take over, and there was still some resistance to doctrines and practices that wanted goodwill to have no impact on profit.

\section{a) The decline of the write-off}

In the doctrine, this decline is clear, at least from around 1945-1970. The leading author of accounting literature at the time was the renowned Paton (1962), who like other authors such as Walker (1953), Kripke (1961), Hylton (1964; 1966) and Wolff (1967, p. 258), was in favour of dynamic approaches and against goodwill write-offs. His opponents were only minor authors, often practitioners such as Catlett and Olson (1968), and Spacek (1973).

The decline is just as obvious in the regulations (AAA, 1948, p. 340; AIA, 1953, p. 39-40). The AIA's basic position was that acquired goodwill should be systematically amortized by reduction of current income. But write-offs were still allowed. A decisive attack on this stand came in 1966 in the form of APB Opinion No. 9 concerning prior-period adjustments. This argued that write-offs should in principle be charged against current income.

The decline of the write-off was equally strong in practice (Hughes, 1982, p. 156). The reasons for the declining popularity of the practice are not clear (see Kripke, 1961, p. 1029, note 3; Spacek, 1973), but apparently concern the aim to avoid (1) elimination of reserves that were useful for dividend distribution; (2) a sudden impact on reserves and (3) reduction of the financial surface of the firm. 


\section{b) The rise to dominance of the dynamic approach}

The move towards the dynamic approach happened slowly. It probably began in the 1930s, a period of serious economic depression when businesses tried to reassure shareholders by providing a "smoothed" (to apply a modern term) presentation of income. But in a context of economic crisis, with conservative approaches still very strong at the time (Kripke, 1961, p. 1032), it was too early for full application of this "new” doctrine, at least for goodwill. It was only in the 1960s and 1970s that the dynamic doctrine came to dominate in treatment of goodwill, at a time when stock markets were sluggish, demonstrating that creditor protection was no longer a concern of the state (decline of the stakeholder model).

Although it was not absolute, this domination is clear in both regulations and practices. In terms of regulations, the main official document reflecting the domination of dynamic practices is APB Opinion No. 17 of 1970, which stipulates that goodwill must be "amortized by systematic expenses over a certain period”. This effectively cancelled out the options left open by ARB 43 ch. 5, which had favoured write-offs.

\section{c) Continued opposition}

It is always difficult to satisfy all companies, as they all operate in different conditions. APB 17 was adopted by 13 votes for over 5 against, indicating significant "resistance" to the dynamic approaches.

\section{Resistance from the weakened static view}

For some companies, busy around 1970 with massive mergers on a scale the United States had never seen before, the prospect of having to amortize enormous amounts of goodwill even over 40 years - was problematic. The regular reduction in income that would result was felt to be a less satisfactory solution than a reduction in reserves or equity (Catlett \& Olson, 1968; see also Miller, 1973, p. 280, 291; Colley \& Volkan, 1988, p. 41). 


\section{Pooling of interests}

In parallel to the "doctrinal resistance”, pressure was put on members of the APB, with a certain degree of success. The result was a "modern" and "beneficial" version of the static solution: pooling of interests. Until 1950, the only business combination method that existed was the purchase accounting method (Catlett \& Olson, 1968, p. 45). Pooling of interests was “discovered” in 1950 with ARB 40 (AIA, 1950), but was not of great interest until 1957 because the write-off method was neither yet discredited nor prohibited. But starting from 1957, in a high-inflation context that saw goodwill values shoot up, pooling began to play a strategic role for companies who were reluctant to amortize and wished to carry on using practices similar to write-offs (Catlett \& Olson, 1968, p. 3-4). Throughout this period there was great pressure to broaden the criteria for application of the pooling of interests method. The struggle was not yet over: in 1969, the APB considered prohibiting pooling in a political environment calling for checks on mergers, seen as bad for national employment (Spacek, 1972). A prominent author like Briloff $(1967 ; 1968 ; 1979)$ sharply criticized what he called “dirty pooling”. But once again, under pressure from businesses the APB backed down ${ }^{4}$.

In the end, the pooling of interests method could be used by any group undertaking a merger by exchange of stock. While this meant that the write-off technique was no longer as widely accepted as in the previous period, it remained possible to use it in a particularly favourable form (elimination of goodwill with no impact on reserves) for some merger transactions.

\footnotetext{
${ }^{4}$ Interestingly, after the adoption of SFAS 141 and 142, Briloff, in an interview, criticized the new rule because of the leeway it gives management for determining when goodwill has become impaired. Briloff even stated that he had "labored for 30 years to get rid of pooling accounting and [was] sorry [he] did" (interview given to the AIMR's The Financial Journalist E-Newsletter for January 2002 http://www.newswise.com/articles/view/?id=FJJAN.IMR).
} 


\section{Resistance by the actuarial view}

As Hughes (1982) pointed out, there are few references to the actuarial doctrine in publications over the period 1958-1980. Only a few authors, like Knortz (1970), and especially May (1943; 1957; quoted in Catlett \& Olson, 1968, p. 88-89) and Gynther (1969), dared to speak openly in defence of this approach.

After 1972, the dynamic doctrine took over, but the desire to use the actuarial approach remained at the back of the minds of a good many US businesses. This fact is important to fully understand the current situation.

\subsubsection{France $(1982-2005)$}

After a period of more than sixty years' “stagnation” in France, this phase brought sudden signs of a clear change in treatment of goodwill, and the dynamic approach became more popular.

The first sign came in the third postwar official General Accounting Plan issued in 1982. This reintroduced a goodwill amortization account, and stated that "intangible items making up goodwill do not necessarily benefit from legal protection that confers a certain value” (CNC, 1982, p. 120). Thus a degree of incentive for amortization for accounting (rather than tax) purposes appeared.

The move towards the dynamic approach was confirmed by the regulations governing consolidated accounts. Decree 67-236 on companies, amended following the law of 1985 on consolidated financial statements, ruled that unallocated goodwill arising on first consolidation "must be included in income over a period of amortization”, while regulation 99-02, paragraph 21130 of 1999, stated that "the amortization period must... reflect the assumptions used and objectives evidenced at the time of acquisition”.

It is true that even the regulations used the flexibility allowed by the seventh directive, and introduced the possibility for French groups to write off goodwill against reserves. But 
contrary to its German counterpart, the French regulator decreed that this write-off could only happen "in exceptional circumstances duly justified in the notes” (Decree of March 23, 1967 modified in 1986, § 248-3). Clearly, the aim was to restrain the use of the weakened static approach in favour of the dynamic view.

The last issue deserving our attention is pooling. At the beginning of the period, the method was totally absent from French regulations. It was only in 1999 that the French regulator, not wishing to “disadvantage” French groups, decided to introduce this treatment of goodwill into French regulations (CRC, 1999, § 215). But pooling was rarely used for two main reasons. First, it was allowed as an exception, subject to strict conditions. Second, and probably more importantly, it appeared on the French scene not long before the regulator announced plans to put an end to its use.

The final question is why most French companies (with enough influence to achieve substantial change in the regulations) wanted to adopt a dynamic approach. The main reason for the move towards a dynamic approach was, we believe, a process of imitation: in order to build an international reputation, large French companies had to comply with US and/or international rules, i.e. rules which at the time favoured the dynamic treatment of goodwill (IASC, 1993). The third "French" phase was in fact an international phase dictated by the dominant accounting solutions of the worldwide shareholder model (see below).

\subsubsection{Great Britain $(1990-2005)$}

The period from 1990 to the modern day saw the arrival of laws in Britain that either recommended or imposed amortization of goodwill. To fully understand this evolution, we need to look at what was happening in international standards. In 1990 ED 47 (ASC, 1990) recommended systematic amortization of goodwill, but no final draft followed due to fierce opposition by businesses (Brown, 1998, p. 61; Paterson, 2002b). In 1993, a discussion paper (ASB, 1993) also recommended systematic amortization, and in 1997, FRS 10 (ASB, 1997), 
preceded by FRED 12, made capitalization plus systematic amortization over a period of up to 20 years the preferred method, although non-amortization with application of an annual impairment test was also allowed.

As company law required goodwill to be amortized, and considered that non-amortization was justified only if necessary to provide a true and fair view, and even then subject to providing evidence that the goodwill had an indefinite life, it is possible to assert that systematic amortization was the basic new rule.

Overall, in spite of the fact that goodwill was yet not formally recognized as a true asset, the rules were clearly leaning towards the dynamic solution. But an alternative approach was still allowed as an option. This dualistic stance can be interpreted in two ways:

- the most plausible interpretation is that the British standard-setters had to yield to the solutions adopted in the United States and the IASC (1993), which favoured systematic amortization;

- $\quad$ but alternatively, it may indicate that some British businesses were looking to replace the write-off practice by another, more favourable approach: non-amortization with impairment tests. This would make the issue not write-off versus amortization, but writeoff versus the actuarial approach.

\subsubsection{Germany: the (short) dynamic phase (2000-2005)}

In a context of globalization and the rising power of the American corporate governance model, backed by certain international accounting organizations such as the IASB, it is not surprising that there were many calls in Germany at the end of the $20^{\text {th }}$ century to end German “peculiarities” and align practices with the dominant American views.

In 1998, the law "on the facilitation and the reception of capital” (KapAEG) introduced an article (292a) in the German Commercial Code allowing German groups (until 2004) to adopt IAS and even US GAAP for consolidated accounts, provided these rules were compatible 
with the European Directives and the GoB (“Grundsätze ordnungsmässiger Buchhaltung”, i.e. "Principles of proper accounting” - German GAAP).

The DSR (Deutscher Standardisierungsrat - German Accounting Standards Board), a new body charged by the Ministry of Finance to forge new regulations for consolidated accounts, confirmed with its first standard, DRS1 (DSR, 1999), that American rules could be considered as equivalent to the GoB. Then in July 2000, the DSR published DRS4 (DSR, 2000) on the “acquisitions of companies and group accounts”. This DRS, schematically: (1) imposes systematic capitalization of goodwill as an element of the companies' wealth (DRS 4.1f); (2) prohibits all write-offs against equity (DRS 4.27-29); (3) imposes systematic amortization (normally straight-line) over the period of use, up to a limit of 20 years (DRS 4.31). An impairment loss may be booked in addition to this amortization if the recoverable value is lower than the net book value (DRS 4.34). Clearly, as a whole, the DRS espoused the IASC's positions, themselves fundamentally in line with American conceptions at the time.

In 2001 the American standard-setter published SFAS 142 (FASB, 2001b) which rang the death knell for systematic amortization of goodwill, in favour of an actuarial solution (impairment based on the estimation of future cash flows). The DSR faced a dilemma: could it go on asserting that the new American rules were compatible with European and GoB rules?

Despite the warnings of many of the major actors in German doctrine, such as Busse von Colbe (2001, p. 879) and Hommel, (2001, p. 1943), and more broadly the majority of the members of the Scientific Committee for Accounting (Wissenschaftliche Kommission Rechnungswesen) (according to Siegel, 2002, p. 749), the DSR, after an “animated debate”, published DSR1a (DSR, 2002), specifying that the new American doctrine on goodwill did not prevent adoption of FASB standards as a substitute for GoB. It also upheld DSR4 as before. These decisions sent shockwaves around Germany. Even the most moderate of commentators underlined the totally contradictory nature of the two standards, and the 
apparent illegality of the adopted American rule in view of the seventh directive and the GoB (Moxter, 2001, p. 1; Krawitz cited in Siegel, 2002, p. 749; Duhr, 2003, p. 974; Busse von Colbe, 2004; Schildbach, 2005, p. 1). The only remaining hope for these numerous objectors was the possibility of a veto by the German Ministry of Justice. Unfortunately for them, the DSR standard was ratified on April 6, 2002.

As all this shows, the struggle over goodwill has been played out in very dramatic conditions in Germany. Against very strong resistance by the German doctrine to the new American position, the defenders of the new international order needed to force a passage for the new philosophy of impairment, in anticipation of its ratification by the European Union.

\subsection{Phase 4: the actuarial phase}

The ideal dreamed of by authors like May (1957), who had recommended non-amortization of goodwill, came true for the first time independently of any tax considerations in the United States at the end of the second half of the $20^{\text {th }}$ century.

\subsubsection{US (2001 - Nowadays)}

The adoption of an actuarial conception of accounting in the US goes back to the Concept Statements (CS) No. 5 (FASB, 1984) and 6 (FASB, 1985). But its application took time. Only after more than 20 years did the revolution actually happen, with the adoption of SFAS 141 and 142 (FASB, 2001a, 2001b) to supersede APB Opinion No. 16 and 17 (AICPA, 1970a, 1970b), a major event in the United States. Under these new standards, goodwill, whether acquired individually or in a business combination, will no longer be amortized but submitted to an impairment test, by comparing the fair value of reporting unit goodwill with the carrying amount of that goodwill (FASB, 2001b, § 20). These new standards represent a victory for the actuarial approach: goodwill is an asset whose value depends on future factors. 


\subsubsection{Other countries: moving towards the actuarial phase?}

As this article was being written, another important event took place: the adoption in March 2004 of standard IFRS 3 (IASB, 2004b) which replaces IAS 22 (IASC, 1993), and the revised standard IAS 38 (IASB, 2004a). IFRS 3 requires goodwill acquired individually or in a business combination to be recognized as an asset, prohibits amortization of goodwill acquired and instead requires the goodwill to be tested for impairment annually. As the IASB explicitly states (2004b, § IN3), “it would be advantageous for international standards to converge with those of Australia and North America”.

Since all listed EU companies have been obliged to prepare their consolidated financial statements under International Accounting Standards/International Financial Reporting Standards from 2005 onwards (European Union, 2002), the three other countries in our study, Great Britain, Germany and France entered the actuarial phase in 2005, at least for the consolidated financial statements of listed companies.

\section{Discussion}

\subsection{The reasons for the new solution}

The actuarial solution has been seen by some authors as an "optimal" solution in that it enables a business to manage results better (Kleindiek, 2001, p. 2576; Küting \& Reuter, 2005) and, at macroeconomic level during the life of the firm, to increase the mass of assets without diminishing the mass of results, by postponing recognition of impairment to the last moment when companies are in a state of bankruptcy (see Paterson, 2002a, for a similar view). For a short-term oriented manager or shareholder, this actuarial view is much "better" than the pure static view, which leads to massive losses at the beginning of the investment cycle, "better" than the weakened static view, which produces a decrease in equity and so weakens firms' leverage, and even "better” than the dynamic view, which reduces earnings all along the cycle (Richard, 2004a, 2004b). 
Pooling was a good solution for profit but not for the balance sheet: it created "hidden reserves” (Johnson \& Petrone, 2001, p. 101) which was problematic in a context where firms seek to display their "strength" to their shareholders. It also had a very bad reputation and prevented comparability of results (Johnson \& Yokley, 1997; FASB, 1998, 1999; Johnson, 1999, p. 80). The new actuarial solution was seen as "optimal” in the sense that it offered nearly all the "advantages” of pooling, without its “disadvantages”.

It is interesting to note that the actuarial approach was generally judged a good solution by the "elites" of the countries studied at the time (see below).

\subsection{US}

Why was the US the first to refuse the static solution (pure or weakened), first adopting the dynamic solution then switching to the actuarial approach, and why did it take the other countries so long to choose the dynamic and actuarial solutions?

As far as the US is concerned, our study is in line with recent research by economists, especially Lazonick and Sullivan (LS in the rest of the paper) (2000) and Aglietta and Rébérioux (AR in the rest of the paper) (2004). These authors have shown that "corporate governance for most US corporations, from their emergence in the late nineteenth and early twentieth century through the 1970s, was based on the strategy of retain and reinvest” (LS, p. 24). They have also shown that throughout this period, the pressure of professional stock market investors was very low (LS, p. 31) and that "top managers tended to be integrated with the business organizations that employed them” (LS, p. 24) which means that the power was generally in the hands of block shareholders and banks (stakeholder model). Our study shows that this retain-and-reinvest strategy was nevertheless in decline as the accounting system moved from a pure static to a dynamic stance. The reason for this decline is presumably linked to the "conglomeration mania" and "massive expansion of corporations that had occurred during the 1960s" that "resulted in poor performance" and "huge debt burdens" in 
the 1970s (LS, p. 15-17): to cope with this situation, big American corporations were obliged to switch their accounting system to a dynamic solution.

Due to international competition, the American economy turned towards a more financial approach with a focus on short-term gains (LS, p. 15-16). There was progressive deregulation of the banking sector in favour of savings and loans institutions (LS, p. 17), and rapid development in pension and mutual funds. This rise in the importance of professional shareholders was accompanied by a fall in the strength of trade unions, as job tenure diminished (LS, p. 19-21). All these converging factors explain why the power went to shortterm oriented professional shareholders, and why there was a strong trend towards maximum short-term profits, with distribution of massive dividends evidenced by the rising pay-out ratios in the 1980s and 1990s (LS, p. 22, AR, p. 83). It is no wonder that abandoning the dynamic solution for the actuarial solution was the natural consequence of this evolution.

In the course of this development, managers disappeared from the scene. Their role in the power game is, of course, contested. According to the famous Berle and Means thesis (1932), in most large American companies, managers achieved power due to the dispersion of shares. This theory has also been used as one of the pillars of the agency theory, whose main purpose is to find a way to solve the fundamental conflict between managers and shareholders (Jensen \& Meckling, 1976). But the Berle and Means thesis has been challenged by Zeitlin (1974) and many other authors. This kind of position has been taken up recently by Lazonick and O’Sullivan, who point out that contrary to those who have argued "often without justification, that the managers who control the allocation of corporate resources and returns are selfserving in the exercise of this control”, "shareholders and [our emphasis] top managers have certainly benefited under the rule of shareholder value” (2000, p. 27).

As far as accounting for goodwill is concerned, it is difficult to find any expression in the American literature of top management opposition to the concealment of systematic amortization of goodwill. Globally speaking it seems, as one leading American economist 
appears to acknowledge (Stiglitz, 2003, p. 175), that managers have followed the holders of power, i.e. the professional shareholders.

The actuarial method adopted in the US also offers an interesting example, supporting the theory developed by Robson (1993) on the gap between the outcomes of accounting regulation and the calculations of actors involved in the process. The major selling point of non-amortization and impairment testing of goodwill is that it should provide accounting numbers closer to the true market value, and therefore more useful to investors. However, "while goodwill impairment must be regularly assessed, the actual application of SFAS 142 results in recognizing goodwill created by the reporting entity subsequent to the purchase combination, to the extent that this replaces or offsets impaired goodwill, so in many cases impairments will not be recognized even when the value of the acquired operations has declined. This approach which reverses the longstanding ban on recognizing created (as opposed to purchased) goodwill was necessitated by the virtual impossibility of separately identifying elements of goodwill having alternative derivations. Even with this simplifying approach, measurement of goodwill impairment is a fairly difficult task, often requiring the services of independent valuation consultants” (Delaney, Nach, Epstein \& Budak, 2003, p. 427). Given that fair values are not readily available for many of the reporting units to which goodwill balances were assigned, managers enjoy a certain amount of discretion when applying this standard (Bens, 2006). Beatty and Weber (2006) show empirically that in the adoption of SFAS 142, firms' equity market concerns affect their preference for above-theline vs. below-the-line accounting treatment of goodwill, and firms' debt contracting, bonus, turnover, and exchange delisting incentives affect their decisions to accelerate or delay expense recognition. 


\subsection{Great Britain}

To continental European actors, Great Britain is often associated with the idea of stock market domination and dispersed shareholders, like the US, possibly to an even greater degree. But this is a false picture. Historians of British business have shown that financial capital and especially stock market capital only began to play a leading role for the majority of large British firms in the 1970s (Wilson, 1995, p. 193), and that "the shareholder preeminence achieved in the 1980s and 1990s, far from being a normal state of affairs, is an anomaly” (Davies, 2002, quoted by Armour, Deakin \& Konzelmann, 2003, p. 2). Before that period, the family firm directed by "gentlemen" (i.e. owner-managers) was the dominant feature of the British economy (Coleman, 1987, p. 8; Gourvish, 1987, p. 33-34; Wilson, 1995, p. 155). It is therefore unsurprising that until that time, self-generated capital was still the most popular means of funding investments (Hannah, 1983, p. 62; Wilson, 1995, p. 129-130). If we add that British banks went on pursuing a conservative strategy, it is easy to understand why the traditional weakened static solution initiated by Dicksee (1897) could have been so successful for so long: it guaranteed satisfaction for both self-financing family owners and prudent bankers alike. This de facto alliance between creditors and long-term investors was particularly acute during the inter-war years, as stressed by Edwards (1989, p. 138) and Maltby (2000), but has had very long-term consequences for goodwill. Of course from the 1970s, with the growing importance of financial capital, the British economy became a kind of dualistic economy, with the persistence of the traditional family firm on one hand, and the rise of international giants financed by external capital on the other. This explains why, when discussion of SSAP 22 was going on in the early 1980s, there was a clash between proponents of the weakened static view and tenants of the dynamic approach. With the era of takeover bids (the second half of the 1980s) and the need to inflate balance sheets in order to ward off predators, the static solution became more and more problematic for many British giants. This, plus the influence of the dominant international solutions of the time, may well explain 
why the dynamic solution emerged in Britain in the 1990s. Although, as Armour et al. (2003, p. 22) underline, the provisions of European Community Directives could be "a major countervailing force to shareholder primacy”, the fact is that in 2002 a significant majority (74\%) of British CFOs stated that companies were eager to apply IAS before 2005, presumably because Great Britain has a strong capital market (Holgate \& Gaul, 2002).

\subsection{Germany}

Germany is the country where the pure or weakened static solutions have taken the longest to disappear. This is not surprising: until quite recently, say the mid-1990s, the environment was very hostile to shareholder value. Only after that period were there signs that a change might be welcome. As is well known, the traditional German system of governance is based on three pillars (Jürgens, Naumann \& Rupp, 2000, p. 59): the banks, co-determination and company-centred management.

Up to 1998 the role of the stock market and private pension funds in German companies’ financing was marginal (Deutsche Bundesbank, 1995, p. 25, cited in Jürgens, Naumann \& Rupp, 2000, p. 62). The power was largely in the hands of the big German families and the banks, but under pressure from employee representatives. These three groups, the basis of the stakeholder model, form the traditional "governing coalition” (Hackethal, Schmidt \& Tyrell, 2003). In 1992 the banks held no less than 61\% of the voting rights of the top 100 listed companies by virtue of proxy votes (Baums \& Fraune, 1995, p. 103). The influence of employee representatives, although variable, was quite important in a majority of supervisory boards (Gerum, 1991). In this context, the problem was not how to create value in the shortterm and distribute dividends, but how to be self-financing, reimburse bank loans and guarantee the stability of the workforce in the long-term. Even German managers, trained as technical rather than financial engineers (Eberwein \& Tholen, 1990), were party to the consensus in favour of accumulation of wealth. No wonder that in these conditions, 
accounting, and accounting for goodwill in particular, was directed towards prudence and retaining income for the sake of creditors and their allies, the managers. This fundamental characteristic has been demonstrated by German authors (Barth, 1953; Döllerer, 1971; Beisse, 1993; Schön, 1997; Moxter, 1998; Weber-Grellet, 1999) as well as French authors (Richard, 2002a).

But in the middle of the 1990s things began to change. A series of inquiries (Förschle, Glaum \& Mandler, 1998) showed that, in a context of market globaliation and the need (partly resulting from German reunification) to find new ways of financing on the Anglo-American stock markets, some top managers in Germany's largest and most internationalized listed companies began to see corporate development along the lines of the model recommended by American consultants and academics, serving shareholder value (see also the examples given by Jürgens, Naumann \& Rupp, 2000, p. 74). Presumably under this influence, the government issued a series of regulations designed to develop a more "Anglo-Saxon" type of management: creation of a "German SEC" (1995) which merged in 2001 with the German Financial Services Authority, abolition of capital gains tax (1998), authorization for the creation of private pension funds (1998), creation of the "new stock market" (1997), abolition of multiple voting rights and restrictions on banks concerning the use of proxy votes and cross-shareholdings (1998), introduction of a mandatory bidding procedure in the new takeover law of 2001, and creation of a new private body for the promotion of international accounting standards.

All these measures, particularly the related rapid development of private pension funds guided by shareholder value principles, significantly changed the landscape and style of management among the elite major listed companies and banks (Jürgens, Naumann \& Rupp, 2000, p. 71). This extremely fast-paced change may explain why listed German groups were allowed to opt for international or even American accounting principles from 1998, and why Brussels encountered no German opposition to adoption of the new international rules 
concerning treatment of goodwill in consolidated accounts. All in all, the famous laws of 1998 on the "Raising of Equity Relief - Kapitalaufnahme-Erleichterungsgesetz" and Kontrag, as described by German authors (Böcking \& Orth, 1998; Claussen, 1998; 1999; Hommelhoff et al., 1999; Haller \& Eierle, 2004), and analyzed by Richard (2002c; 2002b), have encouraged a clear trend towards US management criteria for major German companies.

\subsection{France}

Like Britain, the case of France may appear surprising. In spite of its traditional reputation as state and family-driven (the famous "cent familles" said to control the country), France adopted a dynamic treatment for goodwill (as far as consolidated accounts are concerned) sooner than Germany and even Britain. The explanation is relatively simple. As shown by French economists, notably by Morin (2000, p. 41-42), on the basis of documentation provided by the Banque de France, France is a country where the influence of foreign (especially what the French call “Anglo-Saxon”) investors is very high. By 1985, the share of foreign ownership on the various French stock exchanges had reached 10\%; and it grew to 35\% in 1997. Over that period, probably in line with this shift of power on the stock market, the traditional “cross-shareholding” model was disintegrating, especially after 1996 (Morin, 2000, p. 38). The growing influence of foreign investors, notably the North American pension funds, has driven a new style of management oriented towards shareholder value. During the last ten years, the average duration of shareholding by large investors in French listed firms has decreased from seven years to seven months (de Kerdrel, 2006). Morin (2000, p. 45), after interviews held in 1998 with managers of leading French companies, says he "has been able to verify that this diktat regarding norms is being observed throughout the CAC 40 index companies”. He adds (p. 49) that "many directors admit that it is impossible to escape the demands made by the US and British investors”, which confirms our hypothesis of a link between management and professional shareholders. This evolution in French capitalism from 
a stakeholder towards a shareholder model is also observable in accounting regulations: Colasse and Standish (1998) have shown how membership of the CNC (Conseil National de la Comptabilité - National Accountancy Council), the accounting regulatory body, has rapidly evolved in the nineties in favour of representatives of large (listed) enterprises and audit companies, to the detriment of the public sector. All these factors explain why French accounting legislation on goodwill has, at least since 1985, followed American or international standards.

\subsection{Impact of accounting for goodwill on the shareholder model and the economy}

At the beginning of the article we mentioned the existence of a reverse link between accounting for goodwill and the social and economic environment. The impact of various interest groups on goodwill treatment has been demonstrated throughout, and some attention should now be given to this reverse link.

Even Briloff, a major opponent to pooling of interests as already mentioned, cites one argument often put forward in support of the method: "many business combinations would not have been consummated if 'pooling accounting' were proscribed” (Briloff \& Engler, 1979). The implication is clear: the accounting technique has a direct impact on the economy through the realization of the transaction.

In a report, Plihon (2002) states that the weight of goodwill, compared to equity, is extremely important because of the very high-value acquisitions of the 1990s. Consequently, he anticipates that goodwill amortization will negatively impact prospects for future profits and profitability in the medium term, which could lead to a rise in the level of debt and consequently generate a risk of insolvency and illiquidity.

Plihon's report was written before France's adoption of IFRS. Taking the move to IFRS into account, Boukari and Richard (2006, p. 84, 88) find on a sample of 146 large French listed firms that the adoption of IFRS in 2005 resulted in a 42\% increase in 2004 net income 
(restated to IFRS) compared to the original one (French GAAP ${ }^{5}$ ). More interestingly, $60 \%$ of the increase in net income can be attributed to cancellation of goodwill amortization in favour of impairment. This situation, which can reasonably be expected in other countries switching from goodwill amortization to impairment, provides evidence of the impact of the change in accounting standards on net income, which, in turn favours shareholders.

Combining these two examples, the following assumption can reasonably be reached: beyond the improvement of profit through impairment, the change in accounting regulations for goodwill was also intended to have an economic impact: facilitation of mergers and acquisitions.

Although we can provide no direct evidence for this, we can quote Brown-Humes (2006), who observes a "record amount of mergers and acquisitions in Europe" in 2006, explaining that two key trends encourage M\&A activity: debt is cheap and "corporate balance sheets are healthy". Regarding this second reason, it can safely be assumed that the replacement of goodwill amortization by an impairment test will lead to "healthier" balance sheets, as the reported goodwill will not reduce future equity (as long as a material impairment is not recorded).

Given that the shareholder model "lives on" business combinations, this accounting technique, in facilitating business combination transactions, fosters the trend towards the shareholder model.

\section{Conclusion, limitations and directions for future research}

This article sets out to study the evolution of accounting for goodwill in four countries, Great Britain, the United States, Germany and France, over a period of more than one century. We show that at the outset these four countries were in an identical position, with a static

\footnotetext{
${ }^{5}$ This comparison was possible because all French listed firms were required to publish a comparative table showing the net income for the previous year (i.e. 2004) computed under both sets of standards: IFRS and French GAAP.
} 
vision of accounting for goodwill, and that they are all currently converging towards another common phase using the actuarial approach (recognition and impairment testing). Interestingly, the actuarial view, which is in the process of becoming the dominant practice, was already in existence in the 1900s.

We have attempted to explain this evolution with reference to the stakeholder and shareholder models. While the stakeholder model was the most dominant at the start of the period covered by our study, the shareholder model is clearly the most influential in our own time. The US model was therefore the first to feel the need to change the old system (expensing or charging to reserves), and subsequently the first to adopt amortization, then impairment testing. In the stakeholder model, owners are more concerned for the firm's longterm viability due to their active involvement in management, their understanding of the firm's future prospects and the relative difficulty of exits. In the shareholder model, shareholder-owners have lost patience and even interest in the nuts and bolts of the firm's actual business and are demanding faster and bigger financial returns. We show that there has been an evolution in accounting regulations on goodwill in the four countries studied towards the actuarial phase, which is totally different from the initial phase, the static approach.

We are of course aware that several issues and problems remain and deserve more in-depth analysis and discussion: (1) The alternative theories that could explain the evolution of accounting treatments for goodwill, especially the recent international harmonization of practices; (2) the choice of the four countries studied and the general nature of our analyses; and (3) the suitability of our theory for explaining other accounting changes.

First, as noted earlier, the 'stakeholder vs. shareholder' question is a standard theme in finance and corporate governance literature. However, the long-term vs. short-term orientation may not be the only attribute differentiating these two models. Because of their active involvement in management and greater access to information, owners in the stakeholder model do not need to rely solely on public financial accounting information for 
their decision-making, and are therefore more tolerant of less timely and less decisionrelevant financial reporting based on historical cost. Conversely, investors in the shareholder model use mainly publicly available accounting information for their decision-making and so their demand for timely, “actuarial” disclosure is very high.

The international politics of accounting is also very helpful in understanding why France and Germany (and to a lesser extent, the UK) followed the US on the matter of accounting treatments of goodwill. Examining the interconnections between international politics and accounting professionalization projects at local level in Greece, Caramanis (2002) shows "how intertwined accountancy and the broader socio-economic and political domain are, not only at the local, but also at the international level”. Hirst and Thompson (1995) have emphasized the role of politics in the 'globalization' era, with particular reference to the international accounting profession. They write that "major states may play a pivotal role, while the authority and sovereignty of lesser states may be continuously challenged and negotiated in a realist fashion” (p. 408). Their analysis can easily be applied to the adoption of IAS/IFRS (and therefore the actuarial phase of goodwill treatment) in Europe.

Second, the choice of the four countries in our survey is open to some debate. As explained, they were chosen because they represent the Western world, but we willingly acknowledge that other countries could validly be added to the sample. As an example of a possible future expansion on this article, we present in Appendix 1 the results of a preliminary investigation into a major Asian country, Japan, showing that Japan has reached the dynamic phase but is reluctant to adopt the actuarial phase. Despite this reluctance, it can reasonably be assumed given the current trend towards IFRS that Japan will also converge to the actuarial approach. China could be another interesting example. Its capital market, founded at the beginning of the 1990s, now lists more than 1,400 companies. Most of these companies are still clearly operating under the stakeholder model: a large portion of their shares (around $60 \%$ on average) is held by the State, other State-owned firms or families (Ding, Zhang \& Zhang, 
2007). However, things have been changing very fast in China recently. After the reform of 2005, the State-owned shares in most listed companies became tradable. About 200 mutual funds are now operating in China and foreign investment funds are also allowed to enter, subject to approval. Also, since 2006 stock option incentive plans have begun to spread in Chinese firms. To accompany all these developments China began a major accounting harmonization move on January 1, 2007, adopting accounting standards very close to IAS/IFRS, including the actuarial approach for goodwill treatment, and capitalization of development costs. In this context, the adoption of the actuarial approach is certainly an advantage for short-term oriented investors.

In Japan and China, the international politics of accounting may provide an enlightening analytical framework. These countries, like many others, are having to accept the new rules of the accounting "world game”, because not joining in endangers their participation in the world economy. But the shareholder model remains important in a context of international politics, for two reasons: “contagion” and "acceptance”. "Contagion”, as the word suggests, means that a new type of accounting can only be explained by the emergence of shareholder power in the "key" countries that "set" the rules of worldwide accounting governance. The source of all change is, in our opinion, linked to the history of these key countries. Meanwhile, “acceptance” - willing or under duress - in countries still marked by the stakeholder model of the new game rules that favour shareholder interests can only come about if the country's political power is not fundamentally opposed to shareholder interests.

Finally, another interesting area for exploration would be a search for other balance sheet items that may be facing the same changes as goodwill. As shown by Richard (2005c), France has seen an evolution from the "static" to the "dynamic" phase for most assets. While the actuarial phase may not yet concern tangible fixed assets and most intangible assets, the actuarial value "germ” may well be progressively spreading through the structure proposed by the IASB, particularly as the principle of systematic amortization of intangible assets has been 
abandoned for assets with an indefinite useful life (Richard, 2005c, p. 115). More generally, we have some examples apparently indicating that goodwill cannot be an isolated case: these examples concern long-term investments, development costs and environmental expenses.

The case of long-term investments is particularly interesting. In around 1900, there appears to have been no specific treatment for such items, which were accounted for statically in the same way as short-term investments, with adjustment for changes in their market value (although for reasons of conservatism, often only downward changes were recorded). Then during the $20^{\text {th }}$ century the dynamic view emerged, with a move to differentiation between long-term investments and short-term investments, suggesting that only long-term investments should be valued by the cost method or the equity method, or that market fluctuations that are "other than temporary" should be eliminated. Another frontier was crossed with the arrival of IFRS (see IAS 39, IASB, 2003): for certain items, e.g. financial assets designated at fair value through profit or loss, valuation based on an actuarial method was allowed.

The treatment of development costs also reveals the same trends as those identified in our historical discussion (see Richard, 2004a). In around 1900, the normal accounting method for these costs was immediate expensing (the static view). Then, throughout the $20^{\text {th }}$ century, people argued for capitalization followed by amortization (Richard, 2005c, p. 105), and this dynamic solution was the approach selected by the IAS (see IAS 38, IASB, 2004a), after its initial acceptance for certain restricted situations (in some countries, for example, capitalization was limited to exploration costs only). Actuarial valuation of these expenses may (still?) be a problem, but it can be considered that the new conception of goodwill is encouraging an actuarial approach to treatment of intangibles.

Finally, the treatment of environmental expenses is a recent issue, and was unknown at the start of the $20^{\text {th }}$ century. This makes historical comparison impossible, but a theoretical comparison can be sketched out. Taking the case of dismantling costs for a nuclear power 
plant, for example, the early $20^{\text {th }}$ century lawyers in favour of the static approach would clearly not have approved of capitalizing such expenses, as they relate to a fictitious asset with no liquidation value. And yet this was the approach later taken by IFRS and many of today’s laws. Environmental expenses are capitalized and amortized over a certain period in a standard dynamic approach - and some regulations go further and recommend discounting. This vision, which has attracted severe criticism from proponents of an ecological view that objects to decreasing ecological liabilities to the detriment of future generations, reflects how far actuarial reasoning has penetrated.

We must not allow ourselves to be misled by these examples. There are several others that illustrate opposite trends, precisely because of the multiplicity of influences that can operate simultaneously. In France, for example, now IFRS have been adopted, it is no longer possible to amortize advertising or training costs, and this is a "step backwards" compared to the principles of the dynamic accounting view. The internationalization of accounting can visibly bring certain independent trends in individual countries to an end, but may also be explained in the context of a broader view.

To conclude, meticulous historical and geographic research into the changes in treatment of the main types of asset and liability is necessary to determine whether the theories in this article are of general relevance. We believe that its essential merit is to raise the question of the meaning of accounting capitalism, and offer “old” European accounting theories as an “archetype" (to borrow the term used by Roberts, 1995) to settle the fundamental question of the classification and evolution of accounting systems. 


\section{Appendix 1 - The case of Japan}

\section{$\underline{\text { The static phase (1967 - 1997) }}$}

Group financial reporting is a relatively recent development in Japan compared with the United Kingdom and United States. "Financial reporting in Japan has traditionally emphasized parent company financial statements rather than consolidated financial statements” (Nobes \& Parker, 2006, p. 256). Very little has been written on the Japanese treatment of goodwill. “The AICPA summary of Japanese accounting (1987) notes that intercorporate purchases are rare in Japan” (Dunne \& Rollins, 1992, p. 196).

The rules relating to non-consolidation goodwill and consolidation goodwill are to be found in quite separate sources of authority. The non-consolidation goodwill rules (which are relevant for tax deductibility purposes) come from the Commercial Code, whereas consolidation goodwill is regulated by the Securities and Exchange Law and the Business Accounting Deliberation Council (Cooke \& Kikuya, 1992).

In March 1965, after an accounting scandal involving the use of transactions between subsidiaries to manipulate earnings, the necessity of mandatory consolidated financial statements was recognized. The government requested the Business Accounting Deliberation Council to study requirements for consolidated financial statements. In May 1967, the official report “Opinion on Consolidated Financial Statements” was issued (BADC, 1967). This report was not an officially endorsed accounting standard. On June 24, 1975, the Business Accounting Deliberation Council issued its final opinion "Accounting Principles for Consolidated Financial Statements” (BADC, 1975) which was endorsed the same day by the Ministry of Finance (Ballon, Tomita \& Usami, 1976).

Purchased goodwill (non-consolidation goodwill) (called Noren or Eigyoken), but not consolidation goodwill, is deductible for tax purposes over a period of five years or less (Walton, Haller \& Raffournier, 2003, p. 191). 
The 1967 report (§ 5.4) stated that “a consolidation adjustment [Renketsu Chosei Kanjyo, the term used to refer to goodwill in Japan] can be amortized for certain periods in the consolidated financial statements. If it is of a small amount, it can be charged in the income statement of that period”. There is no specified amortization period. It should not however be forgotten that the 1967 report was merely an opinion, and had no legal backing.

The 1975 Opinion, which is the first endorsed accounting standard on consolidation, requires that goodwill arising on consolidation must be amortized by not less than the average annual amount over its estimated useful life, with no maximum period specified. However, the Commercial Code provides that [non-consolidation] goodwill shall be amortized by not less than the average annual amount within five years after the acquisition. In practice, therefore, [consolidation] goodwill is amortized within five years or written off immediately in the profit and loss account, in accordance with the requirements of the Commercial Code (Nobes, 1991, p. 64; Cooke \& Kikuya, 1992, p. 210; Lee \& Choi, 1992, p. 222; Cooke, 1993, p. 465; Nobes, 1993, p. 50; Nobes \& Norton, 1996, p. 183, table 2, p. 184, table 3; Sakurai, 1996, p. 485; Nobes \& Norton, 1997, p. 139).

\section{No weakened static phase}

This phase is identifiable in all the countries except France, as mentioned earlier, and Japan. The Japanese situation can probably be explained by the relatively late arrival of regulations on goodwill. When the 1967 and 1975 texts were published, it was necessary to educate companies, and amortization over a short period appeared the most "reasonable" solution, particularly as it was in line with the treatment applicable for non-consolidation goodwill.

\section{The dynamic phase (1997-Nowadays)}

An amendment to the consolidation policy and procedures (BADC 1975 Opinion) was released in 1997 and became effective from fiscal years beginning on or after April 1, 1999. Major changes for business combinations resulting from acquisitions include the following: 
the amortization period for the consolidation adjustment, i.e. goodwill, arising on business combinations has been extended from five years to the maximum of 20 years (Walton, Haller \& Raffournier, 2003, pp. 191-192). Japanese companies had complained that this five-year period fell far short of the 40 years allowed for US companies, and could be an obstacle to their M\&A strategies. The new Japanese regulation corresponds to the period specified in the IASC standards.

The BADC also issued a Statement of Opinion, “Accounting for Business Combinations”, on October 31, 2003. This standard, which does not replace the 1975 Opinion, as it deals with purchased (non-consolidation) goodwill, states that goodwill is to be systematically amortized over 20 years or less, and must also be subject to an impairment test. The standard is effective for fiscal years beginning on or after April 1, 2006. By issuing this text, the BADC has aligned the treatment of non-consolidated accounts and consolidated financial statements.

\section{$\underline{\text { Resistance to the actuarial view }}$}

Japan can be considered as a "recalcitrant" country. In a letter sent to the IASB dated November 2, 2001, the Chairman of the ASBJ (Accounting Standards Board of Japan) wrote the following: "We are opposed to non-amortization of goodwill (...) and we believe that goodwill should be amortized within a certain period and be subject to impairment when necessary”6 . On April 2, 2003, The Japanese Institute of Certified Public Accountants sent a comment letter to the IASB on ED 3, taking a position similar to that expressed by the ASBJ in $2001^{7}$.

In a release published in January 2006, the ASBJ stated that “as a new Japanese standard on business combinations will become effective in 2006, the ASBJ will make at least a tentative

\footnotetext{
${ }^{6}$ This letter can be found on the ASBJ website (http://www.asbj.or.jp).

${ }^{7}$ This letter can be found at the following address: http://www.jicpa.or.jp/n_eng/e20030402.pdf.
} 
decision after reviewing the responses from market participants, the implementation of IFRSs and new developments discussed by the IASB and the FASB" ${ }^{\text {8. }}$

There are several explanations for Japan's “resistance” to the actuarial view. First, Japanese accounting came late to the practice of consolidated accounts. Second, the ASBJ declared in 2001: “We consider that IASB's intention to set up the accounting standard for goodwill by uncritical reference to the new standard in the United States is too hasty. This new standard has only just been issued in July 2001 and, in particular, the appropriateness of nonamortization approach and validity of impairment tests have not yet been verified at all. The IFRS, as an internationally accepted accounting standard, should be carefully established with discretion and we believe that verification of the effectiveness of the new US standard is necessary even if we are merely referring to it" ${ }^{\text {"9 }}$. This statement indicates a certain reluctance to apply a rule without attentive examination and analysis. Third, the stakeholder model is much stronger in Japan than the four countries in our main study. "At the end of World War II, Japan was confronted with the enormous task of rebuilding its war-torn economy. With a limited equity market and savings destroyed, government-supported debt financing was the only available source of funds. Encouraged by the government and financed by the Bank of Japan, new enterprise groupings were formed around Japan's major commercial banks. These new Keiretsu replaced the former Zaibatsu, huge pre-war conglomerates, as the major engines of Japan's post-war economic expansion and the ones most likely to need access to the US securities market. Interdependence was fostered among Keiretsu group companies through financial, commercial, and personal ties. Under such arrangements, the relationships between the borrowing company, related companies, and their bank were very close. Cross shareholdings between borrower, related companies, and the bank were common” (Choi et al., 1983).

\footnotetext{
${ }^{8}$ This release can be found at the following address: www.iasplus.com.

${ }^{9}$ Source: ASBJ website (http://www.asbj.or.jp).
} 
Furthermore, the impact of goodwill on earnings is a less significant issue in Japan. Due to anxiety over individual "loss of face", there has traditionally been a Japanese aversion to individualized financial performance-by-results appraisal and reward systems (Hopper, Koga \& Goto, 1999, p. 76) and accordingly Japanese accounting for goodwill is more influenced by the interests of long-term-oriented stakeholders. This is confirmed by Suzuki (2007) who develops the idea that accounting can do much more than simply promote transparency and comparability of companies for the sake of shareholders and investors, having in mind the accounting's impacts on local economies and societies.

Meanwhile, as noted by Hopper et al. (1999, p. 80-81), the Japanese economic and business world has been changing as a consequence of financial crises. "Since the banks are struggling with bad loans, companies that previously relied upon banks for funding are now forced into self-financing or must go directly to financial markets [our emphasis]”. In this new institutional context, we can reasonably expect that sooner or later, Japan will also enter the actuarial phase for its accounting regulations on goodwill. 


\section{References}

AAA (1948). Accounting concepts and standards underlying corporate financial statements. The Accounting Review, 22(4), 339-344.

Aglietta, M. \& Rebérioux, A. (2004). Dérives du capitalisme financier. Paris: Albin Michel.

AIA (1917). Uniform accounting. Journal of Accountancy, 23(6), 401-433.

AIA (1950). Accounting research bulletin (ARB) No. 40: Business combinations. New York: American Institute of Accountants.

AIA (1953). Accounting research bulletin (ARB) No. 43: Restatement and revision of accounting research bulletins, chapter 5, 'accounting for intangible assets' and chapter 7c 'business combinations'. New York: American Institute of Accountants.

AICPA (1970a). APB opinion No. 16: Business combinations. New York: American Institute of Certified Public Accountants.

AICPA (1970b). APB opinion No. 17: Intangible assets. New York: American Institute of Certified Public Accountants.

Amiaud, A. (1920). Traité théorique et pratique des comptes de réserves dans les sociétés anonymes. Paris: Librairie Sirey, 2nd ed.

Armour, J., Deakin, S. \& Konzelmann, S. J. (2003). Shareholder primacy and the trajectory of UK corporate governance. Working Paper No. 266.

Arnold, J., Eggington, D., Kirkham, L., Macve, R. \& Peasnell, K. (1994). Goodwill and other intangibles: Theoretical considerations and policy issues. London: Institute of Chartered Accountants in England and Wales.

ASB (1993). Discussion paper: Goodwill and intangible assets. London: Accounting Standards Board.

ASB (1997). Financial reporting standard (FRS) 10: Goodwill and intangible assets. London: Accounting Standards Board.

ASC (1984). Statement of standard accounting practice (SSAP) 22: Accounting for goodwill. London.

ASC (1990). Exposure draft 47: Accounting for goodwill. London: Accounting Standards Committee.

BADC (1967). Opinion on consolidated financial statements. Tokyo: Ministry of Finance.

BADC (1975). Opinion on the introduction of consolidated financial statements. Tokyo: Ministry of Finance.

Baetge, J., Kirsch, H.-J. \& Thiele, S. (2002). Bilanzen. Düsseldorf: IDW-Verlag.

Ball, R., Kothari, S. P. \& Robin, A. (2000). The effect of international institutional factors on properties of accounting earnings. Journal of Accounting and Economics, 29, 1-51.

Ball, R., Robin, A. \& Wu, J. S. (2003). Incentives versus standards: Properties of accounting income in four East Asian countries. Journal of Accounting and Economics, 36(1-3), 235-270.

Ball, R. \& Shivakumar, L. (2005). Earnings quality in UK private firms: Comparative loss recognition timeliness. Journal of Accounting and Economics, 39(1), 83-128.

Ballon, R. J., Tomita, I. \& Usami, H. (1976). Financial reporting in Japan. Tokyo, New York \& San Francisco: Kodansha International.

Ballwieser, W. (1996). Accounting treatments for goodwill and other intangible assets in Germany. Issues in Accounting Education, 11(2), 479-481.

Barth, K. (1953). Die Entwicklung des deutschen Bilanzrechts und der auf ihm beruhenden Bilanzauffassungen. Stuttgart: Selbstverlag.

Basu, S. (1997). The conservatism principle and the asymmetric timeliness of earnings. Journal of Accounting and Economics, 24, 3-37.

Basu, S. (2001). Discussion of on the asymmetric recognition of good and bad news in France, Germany and the United Kingdom. Journal of Business Finance and Accounting, 28(9/10), 1333-1349.

Baums, T., Buxbaum, R. \& Hopt, K. (1994). Institutional investors and corporate governance. Berlin: Walter de Gruyter.

Baums, T. \& Fraune, C. (1995). Institutionelle Anleger und Publikumsgesellschaft: Eine empirische Untersuchung. Die Aktiengesellschaft, 40(3), 97-112.

Beatty, A. \& Weber, J. (2006). Accounting discretion in fair value estimates: An examination of SFAS 142 goodwill impairments. Journal of Accounting Research, 44(2), 257-288.

Beaver, W. (1999). Is the stakeholder model dead? Business Horizons, 42(2), 8-12.

Beisse, H. (1993). Glaübigerschutz-Grundprinzip des deutschen Bilanzrechts. In Festschrift für Karl Beusch zum 68. Geburtstag am 31 Oktober 1993 (Ed, Beisse, H.), Berlin/NewYork, 77-97.

Bens, D. A. (2006). Discussion of accounting discretion in fair value estimates: An examination of SFAS 142 goodwill impairments. Journal of Accounting Research, 44(2), 289-296.

Bensadon, D. (2002). La consolidation des comptes chez Pechiney 1960-1985. Mémoire de DEA 124, CREFIGE, University Paris Dauphine.

Berle, A. A. \& Means, G. C. (1932). The modern corporation and private property. New York: MacMillan. 
Berle, A. A. J. (1932). For whom corporate managers are trustees: A note. Harvard Law Review, 45(8), 13651372.

Best, J. W. (1885). Payment of dividend out of capital. The Accountant, December 5, 7.

Bliss, J. H. (1924). Intangible fixed investments. New York: Ronald Press.

Böcking, H. J. \& Orth, C. (1998). Kann das "Gesetz zur Kontrolle und Transparenz im Unternehmensbereich (Kontrag)" einen Beitrag zur Verringerung der Erwartungslücke leisten? die Wirtschaftsprüfung (WPg), 51(8), 351-364.

Böcking, H. J. \& Orth, C. (1999). Mehr Kontrolle und Transparenz im Unternehmensbereich durch eine Verbesserung der Qualität der Abschlussprüfung? Betriebswirtschaftliche Forschung und Praxis (BFuP), 51(4), 418-435.

Bogle, J. D. S. (1889). The writing off of depreciation on the wasting assets of a joint stock company. The Accountant, December 21, 693.

Booth, P. \& Cocks, N. (1990). Critical research issues in accounting standard setting. Journal of Business Finance and Accounting, 17(4), 511-528.

Boukari, M. \& Richard, J. (2006). L'impact du passage aux IFRS sur l'analyse financière de l'information comptable : Quelle révolution ? Paris: CREFIGE, University Paris Dauphine (in collaboration with the Direction des entreprises of the Banque de France).

Bourne, J. H. (1888). Goodwill. The Accountant, September 22, 604-605.

Brière, M. (1934). L'imposition des plus-values et l'amortissement des fonds de commerce. Dissertation. Bordeaux, France.

Briloff, A. J. (1967). Dirty pooling. The Accounting Review, 42(3), 489-496.

Briloff, A. J. (1968). Distortions arising from pooling-of-interests accounting. Financial Analysts Journal, 24(2), 71-80.

Briloff, A. J. \& Engler, C. (1979). Accountancy and the merger movement: A symbiotic relationship. Journal of Corporation Law, 5(1), 81.

Brown, J. (1998). December 1998 - the season of goodwill. Accountancy, 121(1253), 61.

Brown-Humes, C. (2006). On london: M\&a boom to roll on. Financial Times, November 3.

Bryer, R. A. (1995). A political economy of SSAP 22: Accounting for goodwill. British Accounting Review, 27, 283-310.

Burchell, S., Clubb, C., Hopwood, A., Hughes, J. \& Nahapiet, J. (1980). The roles of accounting in organizations and society. Accounting, Organizations and Society, 5(1), 5-27.

Burchell, S., Clubb, C. \& Hopwood, A. G. (1985). Accounting in its social context: Towards a history of value added in the United Kingdom. Accounting, Organizations and Society, 10(4), 381-413.

Busse von Colbe, W. (1986). Bilanzierungshilfe. In Handwörterbuch unbestimmter Rechtsbegriffe im Bilanzrecht (Ed, Leffson, R.), Grossfeld, 86-94.

Busse von Colbe, W. (2001). Ist die Bilanzierung des Firmenwerts nach dem Nonamortization-ImpairmentAnsatz des SFAS-entwurfs von 2001 mit §292a HGB vereinbar? Der Betrieb, (17), 877-879.

Busse von Colbe, W. (2004). New accounting for goodwill: Application of American criteria from a German perspective. In The economics and politics of accounting (Eds, Leuz, C., Pfaff, D. and Hopwood, A. G.), Oxford University Press, 201-218.

Busse von Colbe, W. \& Ordelheide, D. (1993). Konzernabschlüsse. Gabler.

Caramanis, C. V. (2002). The interplay between professional groups, the state and supranational agents: Pax americana in the age of 'globalisation'. Accounting, Organizations and Society, 27(4-5), 379-408.

Catlett, G. R. \& Olson, N. O. (1968). Accounting research study No. 10: Accounting for goodwill. New York: American Institute of Certified Public Accountants.

Charpentier, J. (1906). Etude juridique sur le bilan dans les sociétés par actions. Dissertation. Paris.

Choi, F. D. S., Hino, H., Min, S. K., Nam, S. O., Ujiie, J. \& Stonehill, A. I. (1983). Analyzing foreign financial statements: The use and misuse of international ratio analysis. Journal of International Business Studies, 14(1), 113-131.

Claussen, C. P. (1998). Wie ändert das KonTraG das Aktiengesetz? Der Betrieb, (4), 177-186.

CNC (1947). Plan comptable général (general accounting plan). Paris: Imprimerie Nationale (Commission de normalisation des comptabilités).

CNC (1968). Consolidation des bilans et des comptes. Paris: Imprimerie Nationale (Conseil national de la comptabilité).

CNC (1978). Consolidation des bilans et des comptes. Paris: Imprimerie Nationale (Conseil national de la comptabilité).

CNC (1982). Plan comptable général (general accounting plan). Paris: Imprimerie Nationale (Conseil national de la comptabilité).

Colasse, B. \& Standish, P. (1998). State versus market: Contending interests in the struggle to control French accounting standardisation. Journal of Management and Governance, 2(2), 107-147.

Coleman, D. C. (1987). Failings and achievements: Some British businesses, 1910-80. Business History, 29(4), $1-17$. 
Colley, J. R. \& Volkan, A. G. (1988). Accounting for goodwill. Accounting Horizons, 2(1), 35-41.

Cooke, T. E. (1993). The impact of accounting principles on profits: The US versus Japan. Accounting \& Business Research, 23(92), 460-476.

Cooke, T. E. \& Kikuya, M. (1992). Financial reporting in Japan. Oxford: Blackwell.

Courcelle-Seneuil, J. C. (1872). Manuel des affaires ou traité théorique et pratique des enterprises industrielles, commerciales et agricoles. Paris: Guillaumin et Cie, 3rd.

CRC (1999). Règles et méthodes relatives aux comptes consolidés, arrêté du 22 juin 1999 portant homologation du règlement 99-02 du 29 avril 1999 du comité de la réglementation comptable (rules and methods relating to consolidated accounts - arrêté of June 22, 1999, approving the regulation No. 99-02 of April 29, 1999, of the accounting regulation committee). Paris: Accounting Regulation Committee.

Dalsace, A. (1944). Essai sur la structure des bilans. Dissertation. Paris, France: Law University.

de Kerdrel, Y. (2006). La bourse à reculons ! Le Figaro, 25 April, 17.

Delaney, P. R., Nach, R., Epstein, B. \& Budak, S. W. (2003). GAAP 2004: Interpretation and application of generally accepted accounting principles. Hoboken, New Jersey: John Wiley \& Sons, Inc.

Delaporte, J.-B. (1808). Commentaires sur le code de commerce - tome 1. Paris: Demonville.

Dickinson, A. L. (1917). Accounting practice and procedure. New York: Ronald Press.

Dicksee, L. R. (1897). Goodwill and its treatment in accounts. The Accountant, (January 9), 40-48.

Dicksee, L. R. \& Tillyard, M. A. (1920). Goodwill and its treatment in accounts. London: Gee and Co, 4th.

Didier, F. (1885). Etude sur l'inventaire des sociétés industrielles. Journal des Sociétés Civiles et Commerciales, February, 128-154.

Ding, Y., Zhang, H. \& Zhang, J. (2007). Private vs state ownership and earnings management: Evidence from Chinese listed companies. Corporate Governance, 15(2), 223-238.

Dodd, E. M. J. (1932). For whom are corporate managers trustees? Harvard Law Review, 45, 1145-1163.

Döllerer, G. (1971). Zum Gewinnbegriff des neuen Aktiengesetzes. In Festschrift für Gessler, Verlag Franz Vahlen, 93-110.

Driver, C. \& Thomson, G. (2002). Corporate governance and democracy: The stakeholder debate revisited. Journal of Management and Governance, 6, 111-130.

DSR (1999). DRS N1 Befreiender Konzernabschluss nach §292a HGB. Berlin: Deutscher Standardisierungsrat.

DSR (2000). DRS N4 Unternehmenserwerbe im Konzernabschluss. Berlin: Deutscher Standardisierungsrat.

DSR (2002). DRS N1a: Befreiender Konzernabschluss nach US GAAP: Goodwill und andere immaterielle Vermögenswerte des Anlagevermögens. Berlin: Deutscher Standardisierungsrat.

Duhr, v. A. (2003). Grundsätze ordnungsmäßiger Geschäftswertberichterstattung: Berichtspflichten durch Bilanzierung und Erläuterung nach HGB und US-GAAP. Zeitschrift für Betriebswirtschaft (ZfB), 73(9), 963988.

Dunne, K. M. \& Rollins, T. P. (1992). Accounting for goodwill: A case analysis of the U.S., U.K. and Japan. Journal of International Accounting, Auditing \& Taxation, 1(2), 191-207.

Duplessis (1903). Prescriptions comptables dans les actes des sociétés par actions. Revue des Sociétés, June, 236-244 and 287-295.

Eberwein, W. \& Tholen, J. (1990). Managermentalität: Industrielle Unternehmensleitung als Beruf und Politik. Frankfurt: Frankfurter allgemeine Zeitung.

Edwards, J. R. (1989). A history of financial accounting. Routledge.

Ellrott, H. (2003). Kommentierung zu §285 HGB. In Beck'scher Bilanz , Kommentar, Berger, München.

Esquerré, P. J. (1927). Accounting. New York: Ronald Press.

European Union (2002). Regulation (EC) No 1606/2002 of the European parliament and of the council of 19 July 2002 on the application of international accounting standards. Official Journal of the European Communities, September 11, 2002, L. 243/1 - L. 243/4.

FASB (1980). Concepts statement No. 2: Qualitative characteristics of accounting information. Norwalk, CT: Financial Accounting Standards Board.

FASB (1984). Recognition and measurement in financial statements of business enterprises. Concepts statement No. 5. Norwalk, CT: Financial Accounting Standards Board.

FASB (1985). Elements of financial statements. Concepts statement No. 6. Norwalk, CT: Financial Accounting Standards Board.

FASB (1998). Methods of accounting for business combinations: Recommandations of the G4+1 for achieving convergence. Norwalk, CT: Financial Accounting Standards Board.

FASB (1999). Exposure draft: Business combinations and intangible assets. Norwalk, CT: Financial Accounting Standards Board.

FASB (2001a). Statement of Financial Accounting Standards (SFAS) No. 141: Business combinations. Norwalk, CT: Financial Accounting Standards Board.

FASB (2001b). Statement of Financial Accounting Standards (SFAS) No. 142: Goodwill and other intangible assets. Norwalk, CT: Financial Accounting Standards Board.

Fogarty, T. J., Hussein, M. E. \& Ketz, J. E. (1994). Political aspects of financial accounting standard setting in the USA. Accounting, Auditing \& Accountability Journal, 7(4), 24-46. 
Förschle, G. (1995). Kommentierung des §309 EGB. In U.A. (hrgs) Beck'scher Bilanz-Kommentar, Handels und Steuerrecht (Ed, Budde.W.D.), München, §§238bis 339 HGB.

Förschle, G., Glaum, M. \& Mandler, U. (1998). Internationale Rechnungslegung und Kapitalaufnahmeerleichterungsgesetz-Meinungswandel bei Führungskräften deutscher Unternehmungen ? Der Betrieb, (46), 2281-2288.

Förschle, G. \& Kropp, M. (1986). Wechselwirkungen zwischen Handels-und Steuerbilanz beim Anlagevermögen nach dem Bilanzrichtlinien-Gesetz. die Wirtschaftsprüfung (WPg), 152-161.

Freeman, H. C. (1921). Some considerations involved in the valuation of goodwill. Journal of Accountancy, 32(4), 249-263.

Garke, E. \& Fells, J. M. (1922). Factory accounts in principle and practice. London: Crosby Lockwood and Son, 7th.

Gerum, E. (1991). Aufsichtsratstypen-ein Beitrag zur Theorie der Organisation der Unternehmensführung. Die Betriebswirtschaft (DBW), 51, 719-731.

Gilman, S. (1916). Principles of accounting.

Giner, B. \& Rees, W. (2001). On the asymmetric recognition of good and bad news in France, Germany and the United Kingdom. Journal of Business Finance and Accounting, 28(9-10), 1285-1350.

Gourvish, T. R. (1987). British business and the transition to a corporate economy: Entrepreneurship and management structures. Business History, 29(4), 18-45.

Greve, H. (1933). Die Behandlung der immateriellen Werte in der steuerlichen Erfolgsbilanz. Inauguraldissertation. Würzburg, Germany.

Gundry, W. H. (1902). Goodwill. The Accountant, (June 28), 662-663.

Guthrie, E. (1883). Depreciation and sinking funds. The Accountant, April 21, 6.

Guthrie, E. (1898). Goodwill. The Accountant, April 23, 425-431.

Gynther, R. S. (1969). Some "conceptualizing" on goodwill. The Accounting Review, 44(2), 247-255.

Hackethal, A., Schmidt, R. H. \& Tyrell, M. (2003). Corporate governance in Germany: Transition to a modern capital market-based system? Journal of Institutional and Theoretical Economics, 159(4), 664-674.

Haller, A. \& Eierle, B. (2004). The adaptation of German rules to IFRS: A legislative balancing act. Accounting in Europe, 1, 27-50.

Hamilton, W. R. (1914). Goodwill. The Accountant, February 14, 216-218.

Hannah, L. (1983). The rise of the corporate economy. London and New York: Methuen, 2nd.

Harris, W. (1884). Goodwill. The Accountant, April 5, 9-14.

Harrison, G. L. \& McKinnon, J. L. (1986). Culture and accounting change: A new perspective on corporate reporting regulation and accounting policy formulation. Accounting, Organizations and Society, 11(3), 233252.

Hatfield, H. R. (1918). Modern accounting: Its principles and some of its problems. New York: D. Appleton and Company.

Hatfield, H. R. (1927). Accounting: Its principles and problems. New York: D. Appleton and Company.

Higson, C. (1998). Goodwill. British Accounting Review, 30, 141-158.

Hirst, P. \& Thompson, G. (1995). Globalization and the future of the nation state. Economy and Society, 24(3), 408-442.

Holgate, P. \& Gaul, M. (2002). IAS is coming-ready or not! Accountancy, 130(1308), 89.

Holgate, P. A. (1990). The history and regulation of goodwill accounting. In Brand and goodwill accounting strategies (Ed, Power, M.), Woodhead-Faulkner, London, 9-19.

Holthausen, R. W. \& Leftwich, R. (1983). The economic consequences of accounting choice - implications of costly contracting and monitoring. Journal of Accounting and Economics, 5, 77-117.

Hommel, M. (2001). Bilanzierung von Goodwill und Badwill im internationalen Vergleich. Recht der Internationalen Wirtschaft, (11), 801-809.

Hommelhoff, P., Krumnov, J., Lenz, H., Mattheus, D. \& Schruff, W. (1999). In Kontrag mehr Kontrolle und Transparenz? Betriebswirtschaftliche Forschung und Praxis (BFuP), (4), 437-453.

Hope, O.-K. (2003). Firm-level disclosures and the relative roles of culture and legal origin. Journal of International Financial Management and Accounting, 14(3), 218-248.

Hope, T. \& Gray, R. (1982). Power and policy-making: The development of an R\&D standard. Journal of Business Finance and Accounting, 9(4), 531-558.

Hopper, T., Koga, T. \& Goto, J. (1999). Cost accounting in small and medium sized Japanese companies: An exploratory study. Accounting \& Business Research, 30(1), 73-86.

Hoppit, J. (1987). Risk and failure in English business 1700-1800. Cambridge University Press.

Hopwood, A. G. (1976). Editorial. Accounting, Organizations and Society, 1(1), 1-4.

Hughes, H. P. (1982). Goodwill in accounting: A history of the issues and problems. Research monograph No. 80. Atlanta: Business Publishing Division, College of Business Administration, Georgia State University.

Hung, M. (2001). Accounting standards and value relevance of financial statements: An international analysis. Journal of Accounting and Economics, 30, 401-420.

Hylton, D. P. (1964). The treatment of goodwill (letters to the editor). Journal of Accountancy, 117(4), 30. 
Hylton, D. P. (1966). Implications of the direct write off of goodwill. The New York CPA, 36(12), 118. IASB (2003). International accounting standard (IAS) No. 39: Financial instruments: Recognition and measurement. London: International Accounting Standards Board.

IASB (2004a). International accounting standard (IAS) No. 38: Intangible assets (revised). London: International Accounting Standards Board.

IASB (2004b). International financial reporting standard (IFRS) No. 3: Business combinations. London: International Accounting Standards Board.

IASC (1983). International accounting standard (IAS) No. 22: Accounting for business combinations. London: International Accounting Standards Committee.

IASC (1993). International accounting standard (IAS) No. 22: Business combinations (revised). London: International Accounting Standards Committee.

Jeffers, E. (2005). Corporate governance: Toward converging models? Global Finance Journal, 16(2), 221-232.

Jennings, R. \& Thompson, R. B. (1996). Accounting for intangibles in the United States. Issues in Accounting Education, 11(2), 491-495.

Jensen, M. \& Meckling, W. (1976). Theory of the firm: Managerial behavior, agency costs and ownership structure. Journal of Financial Economics, 3(4), 305-360.

Johnson, L. T. \& Petrone, K. R. (2001). Tale of two standards. Accountancy, 128(1299), 100-101.

Johnson, L. T. \& Yokley, B. D. (1997). Issues associated with the FASB project on business combinations. Norwalk, CT.

Johnson, T. (1999). No more pooling. Accountancy: International Edition, 123(1270), 80-82.

Jürgens, U., Naumann, K. \& Rupp, J. (2000). Shareholder value in an adverse environment: The German case. Economy and Society, 29(1), 54-79.

Kelly, L. (1983). The development of a positive theory of corporate management's role in external financial reporting. Journal of Accounting Literature, 111-150.

Kester, R. B. (1922). Accounting theory and finance. New York: Ronald Press.

Kleindiek, D. (2001). Neue Goodwill-Bilanzierung nach US-GAAP und europäisches Bilanzrechtstellungnahme zum E-DRS1a. Der Betriebs-Berater, Heft 50, 2572-2577.

Klumpes, P. J. M. (1994). The politics of rule development: A case study of Australian pension fund accounting rule-making. Abacus, 30(2), 140-159.

Knight, A. (1908). Depreciation and other reserves. Journal of Accountancy, 5(3), 189-200.

Knortz, H. C. (1970). Economic realism and business combinations. Financial Executive, April, 48-60.

Kopf, G. (1904). Du calcul de l'amortissement dans les entreprises industrielles. Dissertation. Poitiers, France.

Kripke, H. (1961). A good look at goodwill in corporate acquisitions. The Banking Law Journal, December, 1028-1040.

Küting, K. H. (1997). Der Geschäfts- oder Firmenwert aus der Kapitalkonsolidierung. Eine Bestandsaufnahme in Theorie und Praxis. In Festschrift B. Kropff, 446-471.

Küting, K. H. (2000). Der Geschäfts- oder Firmenwert- ein Spielball der Bilanzpolitik in deutschen Konzernen. Die Aktiengesellschaft, (3), 97-105.

Küting, K. H. \& Reuter, M. (2005). Werden stille Reserven in Zukunft (noch) stiller?-machen die IFRS die Bilanzanalyse überflüssig oder weitgehend unmöglich? Der Betriebs-Berater, 13, 706-713.

La Porta, R., Lopez-de-Silances, F. \& Shleifer, A. (1999). Corporate ownership around the world. Journal of Finance, 54(2), 471-517.

Lancaster, J. (1927). Principles and practice of auditing. London: Cambridge W. Heffer \& Sons.

Laughlin, R. C. \& Puxty, A. G. (1983). Accounting regulation: An alternative perspective. Journal of Business Finance and Accounting, 10(3), 451-479.

Lazonick, W. \& O'Sullivan, M. (2000). Maximising shareholder value: A new ideology for corporate governance. Economy and Society, 29(1), 13-35.

Leake, P. D. (1914). Goodwill: Its nature and how to value it. The Accountant, January 17, 81-90.

Lee, C. \& Choi, F. D. S. (1992). Effects of alternative goodwill treatments on merger premia: Further empirical evidence. Journal of International Financial Management \& Accounting, 4(3), 220-236.

Lemarchand, Y. (1993). Du dépérissement à l'amortissement. Enquête sur l'histoire d'un concept et de sa traduction comptable. Nantes: Ouest Editions.

Letza, S., Sun, X. \& Kirkbride, J. (2004). Shareholding versus stakeholding: A critical review of corporate governance. Corporate Governance, 12(3), 242-262.

Lincoln, E. E. (1923). Applied business finance. New York and Chicago: A.W. Shaw Co.

Ludz, C. (1997). Der neue Firmenwert des Bilanzrichtlinien-Gesetzes: Eine Untersuchung zur Feststellung des Einflusses des Bilanzrichtlinien-Gesetzes auf die Behandlung des Firmenwertes in der Handelsbilanz sowie die damit verbundenen bilanzpolitischen Möglichkeiten und die bilanzpolitische Bedeutung des Firmenwertes. Peter Lang Europäischer Verlag der Wissenschaft.

Mac Kinsey, J. C. \& Meech, S. P. (1923). Controlling the finance of a business. New York: Ronald Press.

Macintosh, J. C. C. (1999). The issues, effects and consequences of the Berle-Dodd debate, 1931-1932. Accounting, Organizations and Society, 24(2), 139-153. 
Magnin, P. (1912). De l'amortissement des immobilisations dans le bilan des sociétés anonymes. Annales de droit commercial, 26, 419-458.

Maltby, J. (2000). The origins of prudence in accounting. Critical perspectives on accounting, 11(1), 51-70.

Matheson, E. (1884). The depreciation of factories and their valuation. London: E and F Son.

May, G. O. (1943). Financial accounting. New York: Macmillan.

May, G. O. (1957). Business combinations: An alternate view. Journal of Accountancy, 103(4), 33-36.

McLeay, S., Ordelheide, D. \& Young, S. (2000). Constituent lobbying and its impact on the development of financial reporting regulations: Evidence from Germany. Accounting, Organizations and Society, 25, 79-98.

Miller, M. C. (1973). Goodwill - an aggregation issue. The Accounting Review, 48(2), 280-291.

Molinier, M.-J. (1846). Traité de droit commercial ou explication méthodique des dispositions du code de commerce - tome 1. Paris: Jourbert.

More, F. (1891). Goodwill. The Accountant, April 11, 282-287.

Morin, F. (2000). A transformation in the French model of shareholding and management. Economy and Society, 29(1), 36-53.

Moxter, A. (1984). Bilanzlehre. Band I. Einführung in die Bilanztheorie. Gabler, 3rd.

Moxter, A. (1998). Probleme des Geschäfts- oder Firmenwerts in der höchstrichterlichen Rechtsprechung. In Festschrift sieben (Eds, Matschke, J. and Schildbach, T.), Stuttgart, 473-481.

Moxter, A. (2001). Deutscher Standardisierungsrat auf Irrwegen. Der Betriebs-Berater, 56(50), 1.

Müller, G. (1915). Die kaufmännische Erfolgsrechnung. Berlin.

Niehus, R. (1986). Protokoll der öffentlichen Anhörung von 24.9.1985. In Bilanzrichtliniengesetz Texte und Entwürfe (Ed, Helmric, H. H.), München.

Nobes, C. (1991). Accounting and financial reporting in Japan. Dublin: Lafferty Publications, 2nd edition.

Nobes, C. (1992). A political history of goodwill in the U.K.: An illustration of cyclical standard setting. Abacus, 28(2), 142-167.

Nobes, C. (1993). Coopers \& Lybrand accounting comparisons: UK - Japan. London: Gee.

Nobes, C. \& Norton, J. (1996). International variations in the accounting and tax treatments of goodwill and the implications for research. Journal of International Accounting, Auditing \& Taxation, 5(2), 179-196.

Nobes, C. \& Norton, J. (1997). Effects of alternative goodwill treatments on merger premia: A comment. Journal of International Financial Management \& Accounting, 8(2), 137-141.

Nobes, C. \& Parker, R. (2006). Comparative international accounting. Harlow: Pearson Prentice Hall, 9th edition.

Oberbrinkmann, F. (1990). Statische und dynamische Interpretation der Handelsbilanz. Düsseldorf: IDWVerlag.

Parker, R. H. (1965). Lower of cost and market in Britain and the United States: An historical survey. Abacus, 1(2), 156-172.

Paterson, R. (2002a). Impairment. Accountancy, 130(1312), 105.

Paterson, R. (2002b). Straining goodwill. Accountancy, 129(1306), 101.

Paton, W. \& Littleton, A. C. (1940). An introduction to corporate accounting standards. New York: American Accounting Association.

Paton, W. A. (1962). Accounting theory. Accounting Studies Press Limited.

Paton, W. A. \& Stevenson, R. A. (1922). Principles of accounting. New York: MacMillan Company.

Peasnell, K. V. (1996). A U.K. Perspective on accounting for goodwill and other intangibles. Issues in Accounting Education, 11(2), 487-489.

Plihon, D. (2002). Rentabilité et risque dans le nouveau régime de croissance. Commissariat Général du Plan $\mathrm{N}^{\circ} 69$, October.

Ponssard, J.-P., Plihon, D. \& Zarlowski, P. (2005). Towards a convergence of the shareholder and stakeholder models. Corporate Ownership \& Control, 2(3), 11-18.

Poujol, G. (1965). Le plan comptable commenté, tome III, comptabilité générale. Paris: Foucher.

Power, M. (1992). The politics of brand accounting in the United Kingdom. European Accounting Review, 1(1), 39-68.

Prospert, P. (1934). Les amortissements industriels en droit commercial et en droit fiscal. Dissertation. Toulouse, France.

Puxty, A. G., Willmott, H. C., Cooper, D. J. \& Lowe, T. (1987). Modes of regulation in advanced capitalism: Locating accountancy in four countries. Accounting, Organizations and Society, 12(3), 273-291.

Richard, J. (1996). Comptabilités et pratiques comptables. Paris: Dalloz.

Richard, J. (2002a). Comment la comptabilité traditionnelle allemande protège les créanciers et les managers : Une étude historique et sociologique. Working paper N²002-01 - CEREG, University of Paris-Dauphine.

Richard, J. (2002b). La crise et la réforme du système de surveillance et d'audit des comptes allemands: La loi KONTRAG de 1998. Working paper N²002-03 - CEREG, University of Paris-Dauphine.

Richard, J. (2002c). La crise et la réforme du système d'information comptable allemand: La loi KAEG de 1998 sur la facilitation de l'ouverture des capitaux. Working paper N²002-02 - CEREG, University of ParisDauphine. 
Richard, J. (2004a). Fair value, le troisième stade du capitalisme comptable ? Le cas de la France. Analyses et documents économiques (Cahiers du Centre Confédéral d'études économiques et sociales de la CGT), 95 and 96(February and June), 75-81 and 43-47.

Richard, J. (2004b). The secret past of fair value: Lessons from history applied to the French case. Accounting in Europe, 1, 95-107.

Richard, J. (2005a). The concept of fair value in French and German accounting regulations from 1673 to 1914 and its consequences for the interpretation of the stages of development of capitalist accounting. Critical Perspectives on Accounting, 16(6), 825-850.

Richard, J. (2005b). Herman Veit Simon, Eugen Schmalenbach et Fritz Schmidt: Les "trois s" de la pensée comptable allemande. In Les grands auteurs en comptabilité (Ed, Colasse, B.), EMS, Paris, 73-90.

Richard, J. (2005c). Les trois stades du capitalisme comptable français. In Les normes comptables internationales instruments du capitalisme financier (Ed, Capron, M.), La Découverte, Paris, 89-119.

Rives, L. (1962). Obsession fiscale et administration des entreprises: Essai sur le rapt de la comptabilité par le fisc. Imprimerie Pechade.

Roberts, A. (1995). The very idea of classification in international accounting. Accounting, Organizations and Society, 20(7-8), 639-664.

Robson, K. (1993). Accounting policy making and "interests": Accounting for research and development. Critical Perspectives on Accounting, 4(1), 1-27.

Roby, A. G. (1892). Goodwill. The Accountant, April 2, 288-293.

Roe, M. (1994). Some differences in corporate structure in Germany, Japan and the United States. Yale Law Journal, 102(8), 1997-2003.

Sakurai, H. (1996). A Japanese perspective on accounting for goodwill and intangibles. Issues in Accounting Education, 11(2).

Schildbach, T. (2005). IFRS 3: Einladung zur "Enronitis". Der Betriebs-Berater, Heft 1, 1.

Schilling, F. (2001). Corporate governance in Germany: The move to shareholder value. Corporate Governance: An International Review, 9(3), 148-151.

Schmalenbach, E. (1908). Die Abschreibung. Zeitschrift für handelswissenschaftliche Forschung (ZfhF), 3, 8188.

Schmalenbach, E. (1919). Grundlagen dynamischer Bilanzlehre. Zeitschrift für handelswissenschaftliche Forschung (ZfhF), 13, 1-50; 65-101.

Schmalenbach, E. (1949). Die Beteiligungsfinanzierung. Köln and Opladen.

Schmidt, F. (1927). Anmerkung zu Schubert's Berechnung des Geschäftswerts. Zeitschrift für Betriebswirtschaft (ZfB), 610.

Schön, W. (1997). Entwicklung und Perspektiven des Handelsbilanzrechts: Von ADHGB zum IASC. Zeitschrift für das gesamte Handelsrecht und Wirtschaftsrecht (ZHR), (161), 133-159.

Schreier, J. (1928). Der Geschäftswert. Dissertation. Hamburg.

Siegel, T. (2002). Zur unsinnigen Bilanzierung eines zufälligen Teils des unbekannten originären Geschäftswerts nach DRS 1a. Der Betrieb, 55(15), 749-751.

Simon, H. V. (1886). Die Bilanzen der Aktiengesellschaften und der Kommanditgesellschaften auf Aktien. Berlin: Verlag von J. Guttentag.

Söffing, G. (1988). Der Geschäfts- oder Firmenwert. In Festschrift Döllerer (Eds, Knobbe and Keuk), 593-614.

Solomons, D. (1978). The politicization of accounting: The impact of politics on accounting standards. Journal of Accountancy, 146(5), 65-72.

Solomons, D. (1983). The political implications of accounting and accounting standard setting. Accounting and Business Research, 13(50), 107-118.

Spacek, L. (1972). Acquisition/merger accounting artificially discriminates against public investors and small businessmen. Financial Executive Institute, Milwaukee, Wisconsin.

Spacek, L. (1973). The merger accounting dilemma - proposed solution. In A search for fairness in financial reporting to the public. Vol 2. Selected addresses and articles by Leonard Spacek, 1969-1973, Arthur Andersen \& Co, Chicago, 1-17.

Stacey, W. E. (1888). Goodwill. The Accountant, September 22, 605-606.

Stern, R. (1907). Die kaufmännische Bilanz. Leipzig.

Stiglitz, J. E. (2003). Quand le capitalisme perd la tête (The roaring Nineties). Paris: Fayard.

Stoney, C. \& Winstanley, D. (2001). Stakeholding: Confusion or utopia? Mapping the conceptual terrain. Journal of Management Studies, 38(5), 603-626.

Sutton, T. G. (1984). Lobbying of accounting standard-setting bodies in the U.K. and the U.S.A.: A Downsian analysis. Accounting, Organizations and Society, 9(1), 81-95.

Suzuki, T. (2007). Accountics: Impacts of internationally standardized accounting on the Japanese socioeconomy. Accounting, Organizations \& Society, 32(3), 263-301.

Take, F. (1939). Der Geschäfts- oder Firmenwert. Inaugural-Dissertation. Köln, Germany.

Tinker, A. M., Merino, B. D. \& Neimark, M. D. (1982). The normative origins of positive theories: Ideology and accounting thought. Accounting, Organizations and Society, 7(2), 167-200. 
Tutticci, I., Dunstan, K. \& Holmes, S. (1994). Respondent lobbying in the Australian accounting standard-setting process : ED 49 (a case study). Accounting, Auditing and Accountability Journal, 7(2), 86-104.

Van Lent, L. (1997). Pressure and politics in financial accounting regulation: The case of the financial conglomerates in the Netherlands. Abacus, 33(1), 88-114.

Vavasseur, M. (1868). Traité théorique et pratique des sociétés par actions. Paris: Imprimerie et librairie générale de jurisprudence, Cosse Marchal et Cie.

Verley, J. (1906). Le bilan dans les sociétés anonymes. Dissertation. Paris, France.

Von Strombeck, J. (1878). Grundkapital, Grundvermögen und Bilanz der AG, insbesondere der Eisenbahngesellschaften. In Archiv für Theorie und Praxis des allgemeinen deutschen Handelsrechts, Vol. 3738, p. 1-33; p. 13-107.

Walker, G. T. (1938a). Goodwill on financial statements. The Accounting Review, 13(2), 174-182.

Walker, G. T. (1938b). Nonpurchased goodwill. The Accounting Review, 13(3), 253-259.

Walker, G. T. (1953). Why purchased goodwill should be amortized on a systematic basis. Journal of Accountancy, 95(2), 210-216.

Walker, R. G. (1987). Australia's ASRB. A case study of political activity and regulatory 'capture'. Accounting and Business Research, 17(67), 269-286.

Walker, R. G. \& Robinson, P. (1993). A critical assessment of the literature on political activity and accounting regulation. Research in Accounting Regulation, 7, 3-40.

Walker, R. G. \& Robinson, S. P. (1994a). Competing regulatory agencies with conflicting agendas: Setting standards for cash flow reporting in Australia. Abacus, 30(2), 119-139.

Walker, R. G. \& Robinson, S. P. (1994b). Related-party transactions: A case study of inter-organizational conflict over the 'development' of disclosure rules. Abacus, 30(1), 18-43.

Walton, P., Haller, A. \& Raffournier, B. (2003). International accounting. London: Thomson Learning, 2nd edition.

Walz, R. (1999). Kommentierung zu §255 HGB. In Handelsgesetzbuch, Kommentar, Vol. 3 (Eds, Balzer, P. and al.), Horn, Berlin.

Watts, R. \& Zimmerman, J. (1978). Towards a positive theory of the determination of accounting standards. The Accounting Review, 53(1), 112-134.

Weber, C. P. \& Zündorf, H. (1989). Der Posten "Geschäfts- oder Firmenwert" im Konzernabschluss. Der Betrieb, (7), 333-340.

Weber-Grellet, H. (1999). Der Massgeblichkeitsgrundsatz im Lichte aktueller Entwicklungen. Der BetriebsBerater, 54(42), 2659-2666.

Weetman, P., Davie, E. S. \& Collins, W. (1996). Lobbying on accounting issues - preparer/user imbalance in the case of the operating and financial review. Accounting, Auditing and Accountability Journal, 9(1), 59-76.

Whitley, R. (1998). Internationalization and varieties of capitalism: The limited effects of cross-sectional coordination of economic activities on the nature of business systems. Review of International Political Economy, 5(3), 445-481.

Whitley, R. (1999a). Competing logics and units of analysis in the comparative study of economic organization. International Studies of Management \& Organization, 29(2), 113-126.

Whitley, R. (1999b). Divergent capitalisms - the social structuring and change if business systems. Oxford: Oxford University Press.

Whitley, R. (2005). How national are business systems? The role of states and complementary institutions in standardizing systems of economic coordination and control at the national level. In Changing capitalisms? Internationalization, institutional change, and systems of economic organization (Eds, Morgan, G., Whitley, R. and Moen, E.), Oxford University Press, Oxford, 190-231.

Willmott, H. C., Puxty, A. G., Robson, K., Cooper, D. J. \& Lowe, E. A. (1992). Regulation of accountancy and accountants: A comparative analysis of accounting for research and development in four advanced capitalist countries. Accounting, Auditing \& Accountability Journal, 5(2), 32-56.

Wilson, J. F. (1995). British business history, 1720-1994. Manchester University Press.

Wolff, W. (1967). Accounting for intangibles. The Canadian Chartered Accountants.

Yang, J. M. (1927). Goodwill and other intangibles. New York: Ronald Press.

Zeff, S. (1978). The rise of 'economic consequences'. Journal of Accountancy, 146(6), 56-63.

Zeff, S. A. (2000). Henry rand hatfield: Humanist, scholar and accounting educator. JAI Press inc.

Zeff, S. A. (2002). 'political' lobbying on proposed standards: A challenge to the IASB. Accounting Horizons, 16(1), 43-54.

Zeitlin, M. (1974). Corporate ownership and control: The large corporation and the capitalist class. American Journal of Sociology, 79(5), 1073-1119. 
Figure 1 - Balance sheet theories - Terminology

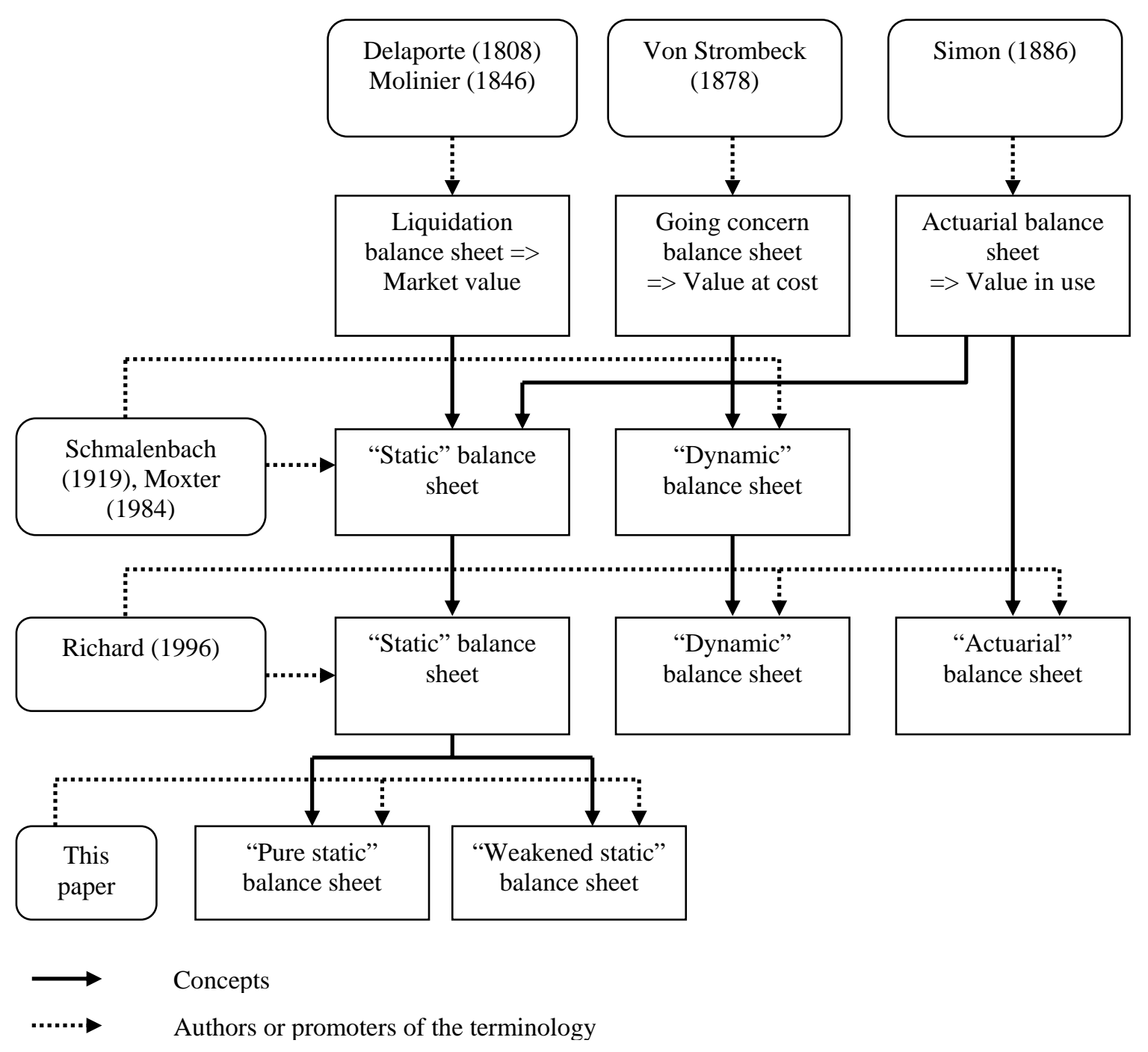


Figure 2 - Summary: Stakeholder/shareholder models, balance sheet theory and accounting for goodwill

\begin{tabular}{|c|c|c|c|}
\hline \multirow{2}{*}{\multicolumn{2}{|c|}{$\begin{array}{l}\text { Stakeholder } \\
\text { influence }\end{array}$}} & $\begin{array}{c}\text { Delayed } \\
\text { negative impact } \\
\text { on profit/equity }\end{array}$ & $\begin{array}{c}\text { Capitalization } \\
\text { without amortization } \\
\text { (but impairment } \\
\text { testing) } \\
\text { Phase } \mathbf{4}\end{array}$ \\
\hline & & $\begin{array}{l}\text { Capitalization with } \\
\text { amortization (over a } \\
\text { long period) } \\
\text { Phase } \mathbf{3}\end{array}$ & \multirow[t]{2}{*}{$\begin{array}{l}\text { Shareholder } \\
\text { influence }\end{array}$} \\
\hline & $\begin{array}{l}\text { Non-capitalization } \\
\text { with write-off } \\
\text { against equity } \\
\text { Phase 2 }\end{array}$ & & \\
\hline $\begin{array}{l}\text { Non-capitalization } \\
\text { (expensing, or } \\
\text { amortization over a } \\
\text { short period) } \\
\text { Phase } 1\end{array}$ & & $\begin{array}{c}\text { Immediate } \\
\text { negative impact } \\
\text { on profit/equity }\end{array}$ & \\
\hline
\end{tabular}


Figure 3 - Summary: The four phases of accounting treatment of goodwill

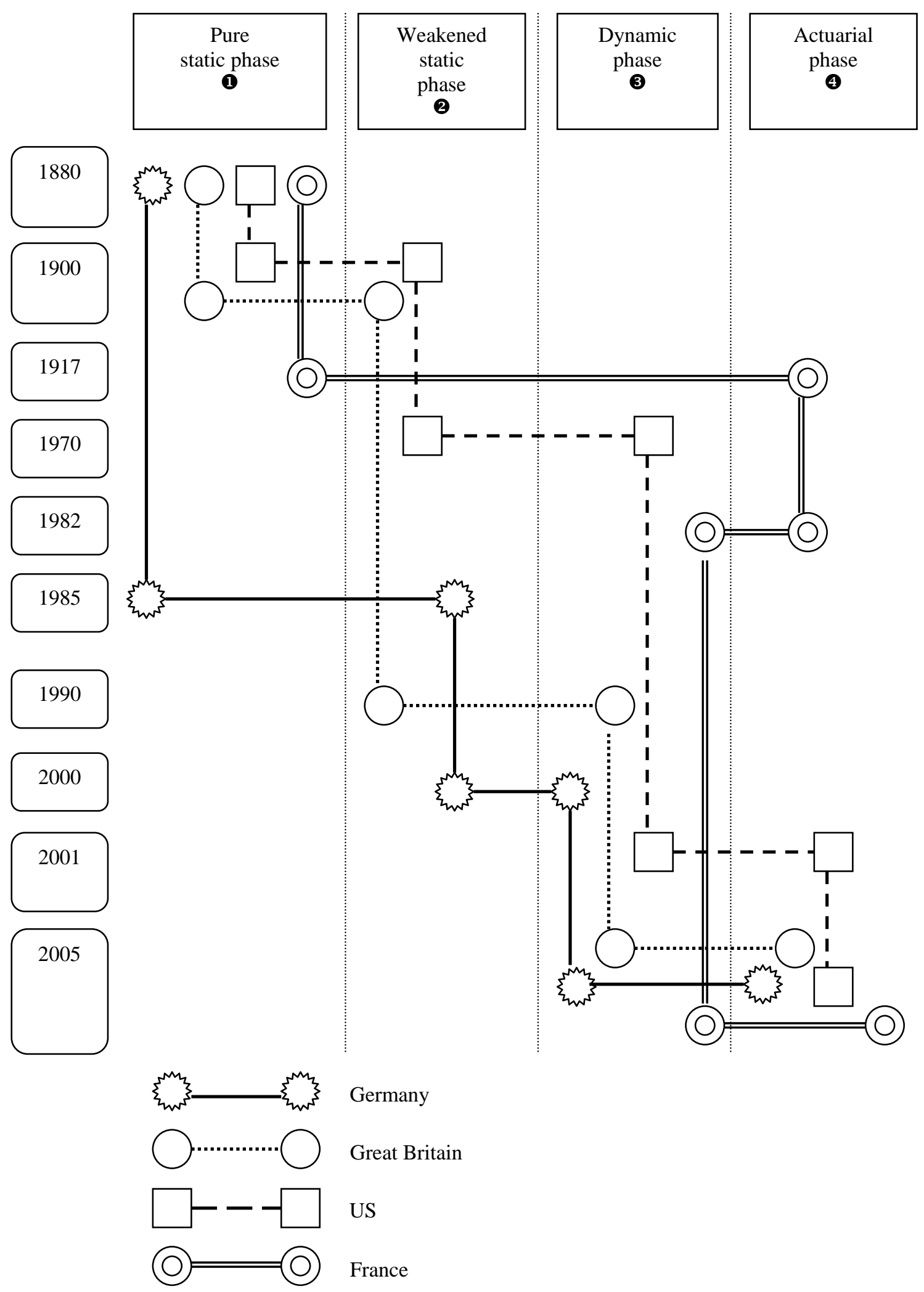

